\title{
Liquid biopsy for therapy monitoring in early-stage non-small cell lung cancer
}

\author{
Misako Nagasaka ${ }^{1,2^{*}}$ (D), Mohammed Hafiz Uddin ${ }^{1}$, Mohammed Najeeb Al-Hallak', Sarah Rahman ${ }^{3}$, \\ Suresh Balasubramanian ${ }^{1}$, Ammar Sukari ${ }^{1}$ and Asfar S. Azmi ${ }^{1}$
}

\begin{abstract}
Liquid biopsy is now considered a valuable diagnostic tool for advanced metastatic non-small cell lung cancer (NSCLC). In NSCLC, circulating tumor DNA (ctDNA) analysis has been shown to increase the chances of identifying the presence of targetable mutations and has been adopted by many clinicians owing to its low risk. Serial monitoring of ctDNA may also help assess the treatment response or for monitoring relapse. As the presence of detectable plasma ctDNA post-surgery likely indicates residual tumor burden, studies have been performed to quantify plasma ctDNA to assess minimal residual disease (MRD) in early-stage resected NSCLC. Most data on utilizing liquid biopsy for monitoring MRD in early-stage NSCLC are from small-scale studies using ctDNA. Here, we review the recent research on liquid biopsy in NSCLC, not limited to ctDNA, and focus on novel methods such as micro RNAs (miRNA) and long non-coding (IncRNA).
\end{abstract}

Keywords: Liquid biopsy, Circulating nucleic acid, ctDNA, ctRNA, miRNA, IncRNA, Therapy monitoring, minimal residual disease (MRD), Early-stage non-small cell lung cancer (NSCLC)

\section{Introduction}

Liquid biopsy has been incorporated in clinical practice as a valuable diagnostic tool for advanced metastatic non-small cell lung cancer (NSCLC). In NSCLC, circulating tumor DNA (ctDNA) analysis is known to increase the chances of identifying targetable mutations and has been postulated clinically as a safer alternative than tissue biopsies.

Circulating cell-free DNA (cfDNA) in the peripheral blood originating from tumors, either in association with nucleosome ( $80-200 \mathrm{bp})$ or encapsulated in extracellular vesicles, is called ctDNA. ctDNA makes its way into the circulation during apoptosis and necrosis of the tumor cells [1]. The increased level of ctDNA in cancer patients results from limited infiltration of immune cells at the

\footnotetext{
* Correspondence: nagasakm@karmanos.org

'Department of Oncology, Wayne State University School of Medicine, Karmanos Cancer Institute, 4100 John R, Detroit, Ml 48201, USA

${ }^{2}$ Division of Neurology, Department of Internal Medicine, St. Marianna University School of Medicine, Kawasaki, Kanagawa, Japan

Full list of author information is available at the end of the article
}

tumor site [2]. Due to intra-tumoral heterogeneity, detection of ctDNAs in liquid biopsies has some advantages over tumor tissue biopsies. ctDNA may offer a representative view of the genetic variations present in the tumor [3] and may provide a "real-time" assessment of the tumor burden, given the typical short half-life of cfDNA (between $16 \mathrm{~min}$ and $2.5 \mathrm{~h}$ ) [4-6].

Typically, the ctDNA fractions in a total cfDNA biofluid samples are very low [7-9], which depends on cancer type and stage, requiring the necessity of highly sensitive detection technologies. Besides quantitative PCR (qPCR) and next-generation sequencing (NGS), recently developed techniques, such as digital PCR (dPCR), droplet digital PCR (ddPCR), and beads emulsion amplification magnetics (BEAMing) are in use to analyze ctDNA [1]. Sequencing approaches include CAncer Personalized Profiling by deep sequencing (CAPP-Seq) [10], Tagged AMplicon deep sequencing (TAM-Seq) [11], Safe-sequencing (Safe-Seq) [12], and Duplex sequencing

(c) The Author(s). 2021 Open Access This article is licensed under a Creative Commons Attribution 4.0 International License, which permits use, sharing, adaptation, distribution and reproduction in any medium or format, as long as you give appropriate credit to the original author(s) and the source, provide a link to the Creative Commons licence, and indicate if changes were made. The images or other third party material in this article are included in the article's Creative Commons licence, unless indicated otherwise in a credit line to the material. If material is not included in the article's Creative Commons licence and your intended use is not permitted by statutory regulation or exceeds the permitted use, you will need to obtain permission directly from the copyright holder. To view a copy of this licence, visit http://creativecommons.org/licenses/by/4.0/ The Creative Commons Public Domain Dedication waiver (http://creativecommons.org/publicdomain/zero/1.0/) applies to the data made available in this article, unless otherwise stated in a credit line to the data. 
[13]. The Integrated Digital Error Suppression (iDES) has further improved the sensitivity of CAPP-Seq [14].

The noninvasive nature of obtaining ctDNA is an advantage in serial monitoring. Several studies have suggested the potential utility of ctDNA monitoring to detect the presence of minimal residual disease (MRD) post-resection in early-stage NSCLC [7, 15-18]. While there are emerging data on utilizing liquid biopsy to monitor MRD in early-stage NSCLC, most are smallscale studies using ctDNA. This paper reviews the current research on liquid biopsy in NSCLC, not limited to ctDNA, and focuses on novel methods such as micro RNA (miRNA) and long non-coding (lncRNA).

\section{Main Text}

\section{Clinical use of ctDNA}

\section{ctDNA and targeted therapy}

The most common scenario, where liquid biopsy utilizing ctDNA would be considered in the clinic, is in the context of newly diagnosed advanced metastatic NSCLC. The utilization of ctDNA has been reported to increase the chances of identifying targetable mutations such as EGFR mutations, ALK fusions, ROS1 fusions, BRAF V600E mutation, ERBB2 (HER2) mutations, RET fusions, MET amplification, and MET exon 14 skipping variants $[19,20]$.

Another common scenario where ctDNA testing could be utilized is perhaps at the time of disease progression in a patient on a tyrosine kinase inhibitor (TKI) treatment. ctDNA can help to identify the mechanism of resistance in such scenarios, and some secondary molecular alterations may be amenable to yet another TKI [21-25].

Indeed, the International Association for the Study of Lung Cancer (IASLC) suggests that liquid biopsy approaches have significant potential to improve patient care, and immediate implementation in the clinic is justified in several therapeutic settings relevant to NSCLC [26].

As the utility of ctDNA testing to guide targeted molecular therapy has been widely assessed through NSCL $C$ patients with EGFR sensitizing mutations, we will use this as an example to reflect on how these tests were incorporated into clinical practice.

The ENSURE study showed that plasma EGFR mutations were useful in detecting patients who would benefit from erlotinib treatment [27]. Data from this study led to the subsequent US Food and Drug Administration (FDA) approval of the Cobas EGFR Mutation Test v2 (Roche Diagnostics, Indianapolis, IN) as the first liquid biopsy test and a companion diagnostic tool to guide treatment choices regarding EGFR TKIs. However, plasma EGFR mutations were detected only in $76.7 \%$ of the patients with EGFR mutations, confirmed from tumor tissues. Therefore, plasma-negative patients are recommended to be retested using tissue samples.
Subsequent data from the AURA phase II extension cohort [28] and AURA2 [29] studies led to the approval of the same method to detect the T790M mutation and determine the eligibility of osimertinib post-1st or-2nd generation EGFR TKIs. These studies reported a testing sensitivity of $61.4 \%$ using plasma, again suggesting the necessity of tissue testing when plasma-based testing is negative.

In addition to the Cobas EGFR Mutation Test v2, the Therascreen EGFR RGQ PCR Kit (Qiagen, Valencia, CA) has been approved by the European agency to detect EGFR mutations when tumor tissue is insufficient. The Qiagen method demonstrated reasonable mutation status concordance of $94.3 \%$ [sensitivity $65.7 \%$, specificity $99.8 \%$, positive predictive value (PPV) $98.6 \%$, negative predictive value (NPV) 93.8\%] among 652 matching tissue/cytology and plasma samples [30].

While osimertinib, a third-generation EGFR TKI, is now considered standard first-line therapy in patients with EGFR-mutated NSCLC [31], clinicians in many parts of the world may be bound by their respective health care system. They may still rely on the use of the first or second-generation EGFR TKIs upfront. Upon progression, it is critical to check for the most common resistance mutation on EGFR, T790M. If EGFR-T790M is detected through ctDNA testing, such patients would be eligible for the use of osimertinib as the second-line agent $[28,29]$. However, if T790M is not detected through ctDNA, in that case, it is suggested that a tissue-based biopsy should be performed due to the possible false-negative results using a plasma-based test and also to rule out other resistance mechanisms, including small cell transformation [32].

Moreover, whether be it the first- or second-line therapy, patients inevitably progress on osimertinib. Acquired resistance, such as EGFR-C797S [21] and various additional alterations, including mutations (BRAF-V600 and $K R A S)$ and amplification (HER2 and MET), have been reported [22, 23]. Detection of such alterations utilizing ctDNA may allow subsequent targeted therapy upon progression on osimertinib [24]. Similarly, plasma genotyping has also been used in NSCLC with other molecular alterations [25].

\section{ctDNA for monitoring MRD after definitive therapy}

Although patients with early-stage NSCLC are treated with curative intent, recurrence remains a challenge. Based on the Lung Adjuvant Cisplatin Evaluation (LACE) meta-analysis, the 5-year-survival of patients treated with adjuvant chemotherapy was only $5.4 \%$ with a hazard ratio (HR) of death at 0.89 (95\% CI 0.82-0.96, $p=0.005$ ) [33]. Consolidation immunotherapy with durvalumab after chemoradiation has shown improved overall survival (OS) and progression-free survival (PFS) 
in unresectable stage III NSCLC. In exchange, over 30\% of patients receiving durvalumab experienced at least one grade 3 or 4 adverse events (AEs) [34]. To truly optimize therapy in the curative setting, it is critical to identify those at high risk of recurrence and provide them with effective treatment.

Previous reports have demonstrated a rapid decline in ctDNA levels post-resection in early-stage lung cancer, which suggests the potential role of ctDNA as a measure of detecting recurrence, possibly before overt disease imaging. By identifying six somatic driver mutations of EGFR, KRAS, TP53, BRAF, PIK3CA, and ERBB2 through targeted sequencing utilizing the SV-CA50ctDNA panel (San Valley Biotech Inc., Beijing, China), Guo et al. reported the changes in tumor and blood ctDNA levels in 41 NSCLC patients before and after surgery. Overall, 19 plasma samples $(19 / 41 ; 46.3 \%)$ were positive for ctDNA before surgery, and among these 19 samples a total of 24 mutations were found including EGFR (17/24; 70.8\%), KRAS (2/24; 8.3\%), TP53 (3/24; $12.5 \%)$, BRAF $(1 / 24 ; 4.2 \%)$, and PIK3CA (1/24; $4.2 \%)$. The average plasma ctDNA mutation frequency prior to surgery was $8.88 \%$ (range: $0.1-81.06 \%$ ), whereas postsurgery it drastically reduced to $0.28 \%$ (range: $0.00-$ $3.01 \%$ ) [15]. A similar study by Chen et al. utilized a 50 gene-panel target sequencing to identify somatic mutations in matched tumor tissue DNA and plasma ctDNA samples. They showed that the average post-operation plasma ctDNA mutation frequency was reduced to $0.28 \%+/-0.32 \%$, from $1.21 \%$ pre-surgery $(p<.0001)$ [16]. Detection of ctDNA post-surgical resection may guide clinicians to consider adjuvant therapy, whereas "non-detection" or reduced detection of ctDNA may be utilized to monitor disease recurrence.

If we know that ctDNA is reduced post-resection, could we then utilize it to monitor disease recurrence? How would we know that we are not detecting random DNA and are monitoring for primary disease recurrence?

Newman et al. developed the CAPP-Seq approach, which combines optimized library preparation methods for low DNA input with multiphase bioinformatics, to design a 'selector' composed of biotinylated DNA oligonucleotides that target recurrently mutated regions in cancers. The selector is applied to tumor DNA to identify the patient's cancer-specific genetic aberrations and then directly to circulating DNA to quantify them over time. The authors give a few examples in NSCLC; a patient with stage IB disease who had surgery and another stage IB patient post-SBRT. In both patients, ctDNA was not detectable after definitive therapy, and both had long-term survival. In contrast, another patient who had chemoradiation for stage IIIB disease had a recurrence following an increase in ctDNA concentration post- therapy, although initial imaging showed a nearcomplete response [10].

Chaudhuri et al. also reported their use of CAPP-Seq to detect ctDNA. In a study of 40 patients treated with curative intent for stage I-III lung cancer, ctDNA was detectable in the first post-treatment blood sample in $94 \%$ of the patients experiencing recurrence [17].

In the TRACERx study, pre and post-surgical plasma ctDNA profiling was performed blinded to relapse status in a sub-group of 24 patients. In this study, multiplexPCR assay panels were synthesized for each patient, targeting clonal and sub clonal single-nucleotide variants (SNVs) selected to track phylogenetic tumor branches in plasma. The multiplex-PCR NGS platform was validated to have a sensitivity of above $99 \%$ for detecting SNVs at frequencies above $0.1 \%$, and the specificity of detecting a single SNV was 99.6\%. At least two SNVs were detected in ctDNA from early-stage NSCLCs that had been analyzed in their discovery cohort data [35], suggesting biological sensitivity of a two-SNV threshold for ctDNA detection. Therefore, a threshold of two detected SNVs for calling a sample ctDNA-positive was selected. In this study's validation cohort, at least two SNVs were seen in 13 out of 14 (93\%) patients with confirmed NSCLC relapse before or during clinical relapse. In contrast, only 1 out of $10(10 \%)$ patients, with no clinical evidence of NSCLC relapse, had at least two SNVs detected [18].

CAPP-Seq is an economical and ultrasensitive method for quantifying ctDNA. By providing personalized profiling through deep sequencing, the clinical application of CAPP-Seq to monitor and detect disease recurrence may become a vital surveillance tool in the future.

\section{ctDNA in treatment monitoring for metastatic NSCLC}

ctDNA testing may help monitor the therapeutic response in the metastatic setting, especially when there is a known driver, such as the sensitizing EGFR mutation. Several studies have evaluated the quantitative changes in serial ctDNA testing and have found a correlation between tumor response and survival.

One of the earlier studies in this area was reported by Mok et al., where ctDNA level was monitored in EGFRmutated patients treated with gemcitabine followed by erlotinib or placebo. In erlotinib-treated patients, the objective response rate (ORR) of those with undetectable ctDNA at 12 weeks was more remarkable than those with detectable ctDNA levels ( $82.5 \%$ vs. $66.7 \%)$. Also, the lack of detectability of ctDNA at 12 weeks was associated with a significant increase in PFS and OS (16.6 vs. 7.8 months and 32.4 vs. 17.7 months, respectively) [36].

Similarly, Taus et al. reported 221 plasma ctDNA correlative samples in response to therapy in 33 EGFR-mutated NSCLC patients treated with TKI or chemotherapy. In 13 of 14 evaluable cases (93\%), ctDNA 
decrease predicted radiological response. Contrastingly, in 17 of 19 evaluable cases (89\%), ctDNA increase predicted radiological progression. In patients with circulating EGFR mutation becoming undetectable during follow-up had a significantly better PFS than those with detectable ctDNA, with a median of 295 vs. 55 days (HR 17.1; $p<0.001$ ), respectively [37].

Monitoring the treatment effects of immunotherapy on NSCLC patients may be uniquely challenging due to an exacerbated inflammatory response that may mimic cancer progression (pseudo-progression). Goldberg et al. compared longitudinal changes in ctDNA levels of 28 NSCLC patients receiving immunotherapy. In this study, a ctDNA response correlated with superior PFS (HR $0.29 ; 95 \% \mathrm{CI}, 0.09-0.89 ; p=0.03)$ and OS (HR 0.17; 95\% CI, 0.05-0.62; $p=0.007$ ) [38]. Interestingly, Lee et al. evaluated the association between ctDNA and pseudoprogression in patients with metastatic melanoma treated with immunotherapy. In this study of 125 patients, the number of ctDNA copies was reduced by more than ten folds within 12 weeks of treatment in those who responded to therapy and also accurately identified all nine patients (7\%) who had pseudoprogression based on imaging [39]. Future studies to evaluate the combination of ctDNA and imaging may further advance the field by measuring treatment response with greater accuracy.

\section{Tumor mutational burden (TMB) in treatment monitoring for metastatic NSCLC}

Another promising biomarker for patients receiving immunotherapy isTMB. Traditionally, TMB is measured using whole-exome sequencing (WES) or an NGS cancer gene panel from the tumor tissue. A high TMB correlates with response to immunotherapy in lung cancer $[40,41]$. Gandara et al. reported that high blood TMB (bTMB), demonstrated by the FDA-approved FoundationOne (F1) CDx NGS assay [42], and was associated with increased PFS with atezolizumab over docetaxel in the second-line treatment for NSCLC. In patients with $\mathrm{bTMB} \geq 16$, a significant increase in PFS with atezolizumab (versus docetaxel) was shown [43]. The B-F1RST study was one of the first prospective trials to evaluate bTMB as a biomarker to predict the benefit of atezolizumab, used in the first-line setting for metastatic NSCLC. Utilizing the same cut-off values of $\mathrm{bTMB} \geq 16$, median PFS was 5.0 vs. 3.5 months, and median OS was 23.9 vs. 13.4 months in the bTMB $\geq 16$ vs. $<16$ patients, respectively [44]. Wang et al. recently showed the concordance of bTMB with matching tumor TMB calculated using WES. In their validation cohort, the investigators reported that a bTMB $\geq 6$ was associated with superior PFS [45]. Georgiadis et al. developed a novel liquid biopsy method utilizing a hybrid-capture-based 98-kb pan-cancer gene panel with multifactorial error correction and peak-finding algorithm. This approach identified TMB and microsatellite instability (MSI) from plasma cfDNA with a specificity of $>99 \%(N=163)$, and sensitivities of $67 \%(N=15)$ and $78 \%(N=23)$, respectively [46]. While testing for TMB and MSI using liquid biopsy appears promising for real-time evaluation and global measurement of a tumor, testing methods need further optimization and validation of cut-off values to be clinically meaningful.

\section{What is circulating non-coding RNA (ncRNA)?}

Circulating genomic materials in the bloodstream encompass nucleotide fragments of DNA and RNA molecules [1]. The RNAs that originate from tumor cells are called circulating tumor RNAs (ctRNAs) [47], which includes both coding and non-coding RNAs (ncRNAs). The ncRNAs comprise a large group of RNAs without the translational ability, involving micro RNAs (miRNAs), transfer RNAs (tRNAs), long non-coding RNAs (lncRNAs), circular RNAs (circRNAs), small nuclear RNAs (snRNAs), small nucleolar RNAs (snoRNAs), and piwi interacting RNAs (piRNAs) [48, 49].

Potential role of ncRNA utilization in monitoring early-stage NSCLC The detection of ncRNA is a noninvasive, innovative approach for diagnosis [1]. As potential biomarkers, ncRNAs were assessed for their ability to provide qualitative and quantitative information (e.g., expression levels), detect the mutational pattern in the transcript, and identify cancer-associated fusion transcripts or alternative splice variants [48]. Among ncRNAs, miRNAs, IncRNAs, and recently characterized circRNAs are more suitable as biomarkers [48]. Cuttingedge technologies, such as ddPCR and comprehensive characterization of RNA using RNASeq, dramatically enhance the probability of ncRNAs as biomarkers. These are capable of detecting new transcripts and can precisely quantify ncRNAs with higher sensitivity [48].

It has been shown that crizotinib-associated clinical outcomes correlated with EML4-ALK fusion transcripts in NSCLC [50]. Nilsson et al. demonstrated that ctRNA extracted from platelets can detect EML4-ALK rearrangements with $65 \%$ sensitivity and $100 \%$ specificity [50]. In an index patient, EML4-ALK fusion transcripts reappeared as ctRNA 2 months before radiographic confirmation of crizotinib resistance. Such detection of fusion RNA transcript in the circulation can help monitor and predict targeted therapies' outcomes [50].

\section{miRNAs as biomarkers}

In 1993, after the discovery of miRNA in Caenorhabditis elegans as an LIN-4 gene transcript [51, 52], the miRNA field advanced immensely with an in-depth understanding 
of its role in human pathobiology [53]. miRNAs are classified as the main category of small ncRNAs. miRNAs consist of 18-25 nucleotides (nts) [54]. miRNAs represent about $3 \%$ of the human genome with 700 members, responsible for the regulation of $20-30 \%$ of coding genes $[55,56]$. Circulating miRNAs have been investigated as biomarker candidates in various types of cancers [57]. The origin of cancer-associated circulating miRNAs is unclear [58]. They may be secreted by circulating tumor cells, tumor cells from the primary site or by cells that have metastasized. The infiltrating immune cells at the tumor microenvironment may also be considered as a source. However, irrespective of their origin, miRNA can be useful biomarkers for tumor progression $[59,60]$. Both radio and chemotherapy can influence the circulating miRNA as evident from several studies [61]. Many patients with earlystage NSCLC require adjuvant chemotherapy. miRNAs may serve as a biomarker to assess such therapy's sensitivity quite early, which playing an important role in patient management decisions and reducing unnecessary therapeutic toxicities [57]. Table 1 summarizes various ctRNAs assessed as a biomarker in NSCLC.

The levels of miR-1246 and miR-1290 in serum were associated with the initiation, progression, and metastasis of NSCLC [62]. miRNA levels correlated with the tumor stage and clinical response and increased by multiple folds compared to healthy controls, suggesting the utility of miR-1246 and miR-1290 as clinical biomarkers [62]. Mutational changes in miRNAs may also predict the outcome of malignancies. Single nucleotide polymorphisms (SNPs) at let-7 complementary sites (LCS) are associated with an increased risk of NSCLC. In a study, 74 NSCLC tissue samples were sequenced to detect mutations at let-7 complementary sites (LCS) in the KRAS 3' untranslated region. Specific LCS6 allelic variant is speculated to be a potential risk factor for NSCLC [63]. Detection of mutated miRNAs in the body fluids of NSCLC patients can be a noninvasive approach to determine the patients at risk.

$\mathrm{Hu}$ et al. investigated serum miRNA levels in longterm (mean survival 49.54 months) and short-term (mean survival 9.54 months) survivors of stage I-IIIa NSCLC [64]. After validation of differentially expressed serum miRNAs in 243 patients, the study suggested a panel of miRNAs, involving miR-486, miR-30d, miR-1, and miR-499, that were linked to survival [64].

In an NSCLC study, patients treated with cisplatin and/or other chemotherapeutic regimens had increased circulating miR-125b. Elevated serum level of miR-125b was indeed associated with inferior OS $(P=0.0012)$ [65]. Upregulation of miR-125b has been reported to inhibit apoptosis caused by cisplatin and associated with cisplatin resistance in breast and ovarian cancers $[66,67]$. The level of miR-125b, therefore, may help in deciding platinum-based chemotherapy response in NSCLC patients. Another study identified a set of 14 circulating miRNA including miR-134, miR-200b, miR-574, miR858 , and let-7c to predict grade $3+$ radiation-induced cardiac toxicity (RICT) in NSCLC [68].

Among other miRNAs, the diagnostic and prognostic potential of serum miR-141 was demonstrated in a prospective cohort study involving 108 NSCLC patients and 54 matched healthy controls [69]. Receiver operating characteristic (ROC) curve analysis showed significant elevation of miR-141 expression in NSCLC patients $(P<$ $0.001)$. Moreover, the expression of miR-141 could distinguish both lymphatic $(P=0.015)$ and distant $(P=$ $0.025)$ metastasis. Subtype analysis revealed an association between miR-141 expression and OS of lung adenocarcinoma but not squamous cell carcinoma [69]. Using multivariate Cox regression analyses, $\mathrm{Xu}$ et al. assessed elevated plasma levels of miR-18a, miR-20a, and miR-92a as prognostic biomarkers for NSCLC [70]. In an approach to combine miRNAs for the diagnosis of NSCLC, Abdollahi et al. suggested a miR-panel (miR-21, miR-148, miR-152 and miR-638) of $96.4 \%$ sensitivity and $86.67 \%$ specificity [71]. Recently, exosomal plasma miRNA of NSCLC patients namely miR-23b-3p, miR10b-5p and miR-21-5p significantly correlated with poor OS (hazard ratio between 2.12-2.42). Several miRNAs in sputum, including miR-21, miR-143, miR-155, miR-210, and miR-372, have also been reported to detect NSCLC earlier $[72,73]$.

\section{Long non-coding RNAs (IncRNAs) as biomarkers}

Aside from miRNAs, another encouraging source of ncRNA-based biomarkers is the lncRNA. IncRNAs are composed of 200 nts or more without any open reading frame but contribute to various cellular activities and diseases, including cancer [74]. There are approximately 60,000 ncRNAs in the human genome; $>70 \%$ are lncRNAs [74]. Only $\sim 20 \%$ of lncRNAs are annotated and shown to modulate diverse cellular functions [75]. The regulation of gene expression by $\operatorname{lncRNAs}$ occurs through cis and trans mechanisms [76, 77]. Additionally, lncRNAs can regulate mRNA splicing and subcellular localization of proteins [78]. Therefore, it is not surprising that abnormal lncRNA expression contributes to cancer development and progression [79].

Recent research on IncRNA has revealed several potential biomarkers for the detection and prognosis of NSCLC. IncRNAs XIST and HIF1A-AS1 were significantly elevated in serum samples of patients with NSCL C [80]. Notably, these were significantly reduced after surgery. Patients with NSCLC and the control group were strongly separated in the ROC curve analysis (area under the curve (AUC) of XIST and HIF1A-AS1 were 0.834 and 0.876 , respectively). The combination of XIST 
Table 1 ctRNAs as a biomarkers in NSCLC

\begin{tabular}{|c|c|c|c|c|c|c|c|}
\hline ctRNAs & Expression & Function & Bio-fluids & $\begin{array}{l}\text { Patients } \\
\text { types }\end{array}$ & $\begin{array}{l}\text { References } \\
\text { (PMID) }\end{array}$ & & \\
\hline \multicolumn{8}{|l|}{ long non coding RNA (IncRNA) } \\
\hline IncRNA MALAT1 & Down & Diagnostic & Whole blood & NSCLC & $\begin{array}{l}26,137,228 ; 24,313 \\
945\end{array}$ & & $\begin{array}{l}\text { Patients vs } \\
\text { healthy } \\
\text { controls }\end{array}$ \\
\hline IncRNA NR-026689 & Up & Diagnostic & Whole blood & NSCLC & $26,908,441$ & & $\begin{array}{l}\text { Patients vs } \\
\text { healthy } \\
\text { controls }\end{array}$ \\
\hline IncRNA XIST & Up & Diagnostic & Serum & NSCLC & $26,339,353$ & & $\begin{array}{l}\text { Patients vs } \\
\text { healthy } \\
\text { controls }\end{array}$ \\
\hline IncRNA HIF1A-AS1 & Up & Diagnostic & Serum & NSCLC & $26,339,353$ & & $\begin{array}{l}\text { Patients vs } \\
\text { healthy } \\
\text { controls }\end{array}$ \\
\hline IncRNA SOX2OT & & $\begin{array}{l}\text { Diagnostic } \\
\text { and } \\
\text { prognostic }\end{array}$ & Serum & NSCLC & $29,504,701$ & & $\begin{array}{l}\text { Patients vs } \\
\text { healthy } \\
\text { controls }\end{array}$ \\
\hline IncRNA ANRIL & & $\begin{array}{l}\text { Diagnostic } \\
\text { and } \\
\text { prognostic }\end{array}$ & Serum & NSCLC & $29,504,701$ & & $\begin{array}{l}\text { Patients vs } \\
\text { healthy } \\
\text { controls }\end{array}$ \\
\hline IncRNA16 (ENST00000539303) & Up & Diagnostic & Plasma & NSCLC & $27,999,202$ & & $\begin{array}{l}\text { Patients vs } \\
\text { healthy } \\
\text { controls }\end{array}$ \\
\hline IncRNA GAS5 & Down & Diagnostic & Plasma & NSCLC & $27,631,209$ & & $\begin{array}{l}\text { Patients vs } \\
\text { healthy } \\
\text { controls }\end{array}$ \\
\hline IncRNA UCA1 & Up & Diagnostic & Plasma & NSCLC & $26,380,024$ & & $\begin{array}{l}\text { Patients vs } \\
\text { healthy } \\
\text { controls }\end{array}$ \\
\hline IncRNA SPRY4-IT1 & Up & $\begin{array}{l}\text { Diagnostic } \\
\text { and } \\
\text { prognostic }\end{array}$ & Plasma & NSCLC & $26,453,113$ & & $\begin{array}{l}\text { Patients vs } \\
\text { healthy } \\
\text { controls }\end{array}$ \\
\hline IncRNA ANRIL & Up & $\begin{array}{l}\text { Diagnostic } \\
\text { and } \\
\text { prognostic }\end{array}$ & Plasma & NSCLC & $26,453,113$ & & $\begin{array}{l}\text { Patients vs } \\
\text { healthy } \\
\text { controls }\end{array}$ \\
\hline IncRNA NEAT1 & Up & $\begin{array}{l}\text { Diagnostic } \\
\text { and } \\
\text { prognostic }\end{array}$ & Plasma & NSCLC & $26,453,113$ & & $\begin{array}{l}\text { Patients vs } \\
\text { healthy } \\
\text { controls }\end{array}$ \\
\hline IncRNA RP11-397D12.4 & Up & Prognostic & Plasma & NSCLC & $26,393,913$ & & $\begin{array}{l}\text { Patients vs } \\
\text { healthy } \\
\text { controls }\end{array}$ \\
\hline IncRNA AC007403.1 & Up & Prognostic & Plasma & NSCLC & $26,393,913$ & & $\begin{array}{l}\text { Patients vs } \\
\text { healthy } \\
\text { controls }\end{array}$ \\
\hline IncRNA ERICH1-ASI & Up & Prognostic & Plasma & NSCLC & $26,393,913$ & & $\begin{array}{l}\text { Patients vs } \\
\text { healthy } \\
\text { controls }\end{array}$ \\
\hline IncRNA AFAP1-AS1 & & Diagnostic & Serum & NSCLC & $29,080,690$ & & \\
\hline IncRNA DLX6-AS1 & & Diagnostic & Plasma & NSCLC & $31,612,030$ & & \\
\hline IncRNA NR-026689 & Up & $\begin{array}{l}\text { Diagnostic } \\
\text { or } \\
\text { prognostic }\end{array}$ & $\begin{array}{l}\text { Cell lines } \\
\text { (human) and } \\
\text { whole blood } \\
\text { (rat) }\end{array}$ & NSCLC & $26,908,441$ & & \\
\hline IncRNA SCARNA7 & & $\begin{array}{l}\text { Diagnostic } \\
\text { or } \\
\text { prognostic }\end{array}$ & Pleural effusions & NSCLC & $31,691,525$ & $\begin{array}{l}\text { EGFR-TKI) therapy } \\
\text { monitoring }\end{array}$ & \\
\hline IncRNA MALAT1 & & Diagnostic & Pleural effusions & NSCLC & $31,691,525$ & EGFR-TKI) therapy & \\
\hline
\end{tabular}


Table $1 \mathrm{ctRNAs}$ as a biomarkers in NSCLC (Continued)

\begin{tabular}{|c|c|c|c|c|c|c|}
\hline ctRNAs & Expression & Function & Bio-fluids & $\begin{array}{l}\text { Patients } \\
\text { types }\end{array}$ & $\begin{array}{l}\text { References } \\
\text { (PMID) }\end{array}$ & \\
\hline & & $\begin{array}{l}\text { or } \\
\text { prognostic }\end{array}$ & & & & monitoring \\
\hline IncRNA NONHSAT017369 & & $\begin{array}{l}\text { Diagnostic } \\
\text { or } \\
\text { prognostic }\end{array}$ & Pleural effusions & NSCLC & $31,691,525$ & $\begin{array}{l}\text { EGFR-TKI) therapy } \\
\text { monitoring }\end{array}$ \\
\hline IncRNA HNF1A-AS1 & Up & & & $\begin{array}{l}\text { Lung cancer } \\
\text { including } \\
\text { NSCLC }\end{array}$ & $25,863,539$ & \\
\hline IncRNA CRNDE & & & & $\begin{array}{l}\text { Lung cancer } \\
\text { including } \\
\text { NSCLC }\end{array}$ & $\begin{array}{l}28,940,804 ; 30,554 \\
121 ; 30,230,527 \\
31,275,444\end{array}$ & \\
\hline $\begin{array}{l}\text { Combined IncRNA GAS5 and } \\
\text { IncRNA SOX2OT }\end{array}$ & & $\begin{array}{l}\text { Diagnostic } \\
\text { and } \\
\text { prognostic }\end{array}$ & Plasma & NSCLC & $31,077,615$ & \\
\hline $\begin{array}{l}\text { IncRNA SOX2OT, ANRIL with } \\
\text { tumor markers CEA, CYFRA21-1 } \\
\text { and SCCA }\end{array}$ & & Diagnostic & Serum & NSCLC & $29,504,701$ & \\
\hline \multicolumn{7}{|l|}{ micro RNA (miRNA /miR) } \\
\hline miR-21 & Up & & & $\begin{array}{l}\text { Lung cancer } \\
\text { including } \\
\text { NSCLC }\end{array}$ & $18,719,201$ & \\
\hline $\begin{array}{l}\text { combination of miR-145 and } \\
\text { miR- } 451\end{array}$ & & Diagnostic & Plasma or serum & $\begin{array}{l}\text { Lung cancer } \\
\text { including } \\
\text { NSCLC }\end{array}$ & $\begin{array}{l}28,060,535 ; 23,301 \\
032\end{array}$ & \\
\hline let-7 & SNP & & & NSCLC & $18,922,928$ & \\
\hline miR-142-3p & & Diagnostic & & NSCLC & $23,410,826$ & \\
\hline miR-125 & Up & Prognostic & Serum & NSCLC & $\begin{array}{l}22,983,388 ; 23,794 \\
259\end{array}$ & $\begin{array}{l}\text { Cisplatin and } \\
\text { pemetrexed-based } \\
\text { chemotherapy }\end{array}$ \\
\hline miR-22 & Up & Prognostic & Serum & NSCLC & $\begin{array}{l}22,983,388 ; 23,794 \\
259\end{array}$ & $\begin{array}{l}\text { Cisplatin and } \\
\text { pemetrexed-based } \\
\text { chemotherapy }\end{array}$ \\
\hline miR-1290 & & Prognostic & Serum & $\begin{array}{l}\text { Lung cancer } \\
\text { including } \\
\text { NSCLC }\end{array}$ & $27,325,363$ & Metastasis \\
\hline miR-1246 & & Prognostic & Serum & $\begin{array}{l}\text { Lung cancer } \\
\text { including } \\
\text { NSCLC }\end{array}$ & $27,325,363$ & Metastasis \\
\hline $\operatorname{miR}-590-5 p$ & & Prognostic & plasma & NSCLC & $31,520,555$ & \\
\hline miR-141 & & $\begin{array}{l}\text { Diagnostic } \\
\text { and } \\
\text { prognostic }\end{array}$ & Serum & NSCLC & $31,938,373$ & \\
\hline miR-18a & Up & Prognostic & plasma & NSCLC & $29,266,846$ & \\
\hline miR-20a & Up & Prognostic & plasma & NSCLC & $29,266,846$ & \\
\hline miR-92a & Up & Prognostic & plasma & NSCLC & $29,266,846$ & \\
\hline $\begin{array}{l}\text { miR-21, miR-148, miR-152 and } \\
\text { miR-638 }\end{array}$ & & Diagnostic & & NSCLC & $31,236,600$ & \\
\hline miR-375 & & $\begin{array}{l}\text { Diagnostic } \\
\text { and } \\
\text { prognostic }\end{array}$ & Serum & $\begin{array}{l}\text { NSCLC } \\
\text { (Indian } \\
\text { patients } \\
\text { cohort) }\end{array}$ & $32,007,320$ & \\
\hline miR-320a & & $\begin{array}{l}\text { Diagnostic } \\
\text { and } \\
\text { prognostic }\end{array}$ & Serum & $\begin{array}{l}\text { NSCLC } \\
\text { (Indian } \\
\text { patients } \\
\text { cohort) }\end{array}$ & $32,007,320$ & \\
\hline
\end{tabular}


Table 1 ctRNAs as a biomarkers in NSCLC (Continued)

\begin{tabular}{|c|c|c|c|c|c|}
\hline ctRNAs & Expression & Function & Bio-fluids & $\begin{array}{l}\text { Patients } \\
\text { types }\end{array}$ & $\begin{array}{l}\text { References } \\
\text { (PMID) }\end{array}$ \\
\hline miR-21 & & $\begin{array}{l}\text { Diagnostic } \\
\text { or } \\
\text { prognostic }\end{array}$ & Sputum & NSCLC & $30,165,346$ \\
\hline miR-143 & & $\begin{array}{l}\text { Diagnostic } \\
\text { or } \\
\text { prognostic }\end{array}$ & Sputum & NSCLC & $30,165,346$ \\
\hline miR-155 & & $\begin{array}{l}\text { Diagnostic } \\
\text { or } \\
\text { prognostic }\end{array}$ & Sputum & NSCLC & $30,165,346$ \\
\hline $\operatorname{miR}-210$ & & $\begin{array}{l}\text { Diagnostic } \\
\text { or } \\
\text { prognostic }\end{array}$ & Sputum & NSCLC & $30,165,346$ \\
\hline miR-372 & $=$ & $\begin{array}{l}\text { Diagnostic } \\
\text { or } \\
\text { prognostic }\end{array}$ & Sputum & NSCLC & $30,165,346$ \\
\hline \multicolumn{6}{|l|}{ circular RNA (circRNA) } \\
\hline $\begin{array}{l}\text { circ-0005962 (up), circ- } \\
\text { 0003958(up), circ-0086414 } \\
\text { (down), circ-0001936 (down) }\end{array}$ & & Prognostic & Plasma & NSCLC & $29,588,350$ \\
\hline circFARSA & & & Plasma & NSCLC & $29,722,168$ \\
\hline \multicolumn{6}{|l|}{ Others } \\
\hline mRNA CCL5 & & Prognostic & & NSCLC & $31,215,484$ \\
\hline mRNA CLU & & Prognostic & & NSCLC & $31,215,484$ \\
\hline mRNA SPARC & & Prognostic & & NSCLC & $31,215,484$ \\
\hline mRNA SRGN & & Prognostic & & NSCLC & $31,215,484$ \\
\hline mRNA with KRAS mutation & & $\begin{array}{l}\text { Diagnostic } \\
\text { and } \\
\text { prognostic }\end{array}$ & & $\begin{array}{l}\text { Lung cancer } \\
\text { including } \\
\text { NSCLC }\end{array}$ & $12,459,728$ \\
\hline snoRD33/66/76 & & Diagnostic & Plasma & NSCLC & $20,663,213$ \\
\hline snoRDs-66 & & & Sputum & NSCLC & $27,176,474$ \\
\hline snoRDs-78 & & & Sputum & NSCLC & $27,176,474$ \\
\hline snRNA U2 (RNU2-1) & & Diagnostic & & $\begin{array}{l}\text { Lung cancer } \\
\text { including } \\
\text { NSCLC }\end{array}$ & $23,527,303$ \\
\hline
\end{tabular}

and HIF1A-AS1 significantly improved the AUC value (0.931) as a predictive biomarker for NSCLC [80]. An increase in exosomal (plasma) lncRNA Distal-less homeobox six antisense RNA 1 (DLX6-AS1) levels were also determined as a potentially promising diagnostic biomarker. The study analyzed 72 serum samples of NSCL $\mathrm{C}$ patients and 64 healthy donors and observed an association with advanced disease, lymph node metastasis and poor tumor differentiation. The sensitivity and specificity were 77.5 and $85.9 \%$ respectively. Notably, the expression of DLX6-AS1 in the serum decreased after surgical resection [81].

Recently, an association between lncRNAs and EGFR mutation was demonstrated. Using the Clariom D Human chip technology, in the plasma samples collected from pleural effusions, three lncRNAs (SCARNA7, MALAT1, and NONHSAT017369) were found to be significantly associated with EGFR mutation and thus could be considered as biomarkers of therapy monitoring [82]. These biomarkers could help predict EGFR mutation status and monitor EGFR-TKI efficacy in patients with EGFR-positive NSCLC.

It is evident from studies that the combination of biomarkers significantly increases the diagnostic and prognostic sensitivity and specificity. Plasma levels of GAS5 and SOX2OT lncRNAs together showed superior sensitivity $(83.8 \%)$ and specificity $(81.4 \%)$ for the diagnosis and prognosis of NSCLC [64]. Circulating GAS5 in combination with other biomarkers can be helpful in monitoring after surgical treatment for NSCLC patients [83]. In a cohort study, serum lncRNA biomarkers SOX2OT and ANRIL, along with tumor markers CEA, CYFRA211, and SCCA, demonstrated higher sensitivity (77.1\%) and specificity (79.2\%) for NSCLC diagnosis [84]. 


\section{circRNAs as biomarkers}

circRNAs were described first in the early 1970s as a non-functional by-product of RNA splicing [85]. They are cell lineage-specific, enriched in exosomes, and observed in different body fluids [86]. Due to its enhanced stability compared to other ncRNAs, they are more suitable as biomarkers for cancer diagnosis, monitoring development, and progression [87]. circRNAs are a large unique family of ncRNAs that have joined covalent ends. They intricate in the complex regulation of normal processes via interacting with proteins, nucleic acids, and other molecules [88-90]. Recently, circFARSA has been detected and confirmed in the plasma of patients with NSCLC, with high confidence $(p<0.001)$ [91], which warrants future studies. The average plasma half-life of circRNAs is more than $48 \mathrm{~h}$, which is much longer than mRNAs $(\sim 10 \mathrm{~h})$ [92]. The hidden 3 ' ends of circRNAs protect them against nuclease-mediated degradations compared to other ncRNAs $[90,93]$. It is assumed that circRNAs overexpressed in lung cancer cells have the potential to be released in the circulation. Such notion has been validated, and indeed a differential expression of circRNAs has been observed in the plasma of early and late-stage NSCLC patients [94]. The study further identified a panel of circRNAs with prognostic significance in NSCLC, which includes two overexpressed (circ-0005962 and circ-0003958) and underexpressed (has-circ-0086414 and has-circ-0001936) circRNAs [94].

snRNA/snoRNAs play essential roles in the early steps of gene expression [95]. Recently, a panel of two snoRNAs, including snoRD-66 and snoRD-78, have been identified in sputum samples of patients with NSCLC. The panel detected NSCLC with $74.6 \%$ sensitivity and $83.6 \%$ specificity, which increased further to $89 \%$ sensitivity and $89 \%$ specificity when combined with miRNAs (miR-21, miR-31, and miR-210) [96].

\section{Potential roles and challenges of ctDNA analysis}

While multiple studies have proven the utility of ctDNA MRD measurement in post-therapy NSCLC patients and may allow personalized MRD-based adjuvant treatment options, they are still challenged by many limitations.

\section{Concordance between the tissue and liquid}

When utilizing ctDNA to detect MRD, it is vital to confirm the concordance rates between plasma samples and the original tumor. A systemic review and meta-analysis of 32 studies with 4527 advanced NSCLC patients reported a pooled sensitivity and specificity of 0.70 and 0.98 respectively for ctDNA EGFR mutation status in plasma samples compared to tumor tissues [97]. The discordance between tumor tissue and plasma DNA likely arises from the limitations of ctDNA detection.

\section{Detection limitation}

Data from the TRACERx study demonstrated that tumor volume correlates with the mean plasma VAF of clonal SNVs in ctDNA-positive NSCLC. A primary NSCLC tumor volume of $10 \mathrm{~cm}^{3}$ predicts a ctDNA plasma VAF of $0.1 \%$. The tumor size may constrain the sensitivity of clonal-SNV ctDNA. It may not also be helpful for the identification of very early disease recurrence or as an initial approach to screen early-stage NSCLC. Lung nodules smaller than computed tomography resolution could release ctDNA with allele frequencies as low as $0.00018 \%$. This would challenge even the most efficient ctDNA technologies, which have reported detection thresholds of $0.00025 \%$ under optimal conditions. While ctDNA-based methods would need improvements in sensitivity thresholds for identifying microscopic diseases, there might still be a challenge of missing very minimal residual disease. Practically, the combination of such technologies with clinical correlation would be critical in evaluating patients.

\section{False positives}

The specificity of ctDNA testing could also be a confronting issue, as not all mutations detected in plasma are related to a cancerous process. For example, BRAF V600E mutation, which is known as the driver mutation in melanoma and NSCLC, is found more frequently in tissue specimens of benign nevi [98]. Indeed, Di Giorgi et al. reported a case where BRAF V600E mutated DNA was detected in both plasma and formalin-fixed tissue specimens from a man with benign nevi [99].

Furthermore, cfDNA primarily originates from hematopoietic cells, and evidence of somatic mutations in these cells are common with aging (10\% in healthy adults $>70$ years), defined as clonal hematopoiesis of indeterminate potential (CHIP) [100]. The presence of CHIP does not necessarily imply the presence of cancer and can confound ctDNA testing results. $\mathrm{Hu}$ et al. reported that most JAK2 mutations, some TP53, and rare KRAS mutations detected in cfDNAs were from clonal hematopoiesis and not tumors. They suggested using paired peripheral blood cells genotyping so that such clonal hematopoiesis-derived mutations would not be misdiagnosed as an occult malignancy [101]. Li et al. reported a novel approach using cfDNA and matching white blood cells with a hybrid capture panel, covering 37 lung cancer-related gene sequencing up to 50,000x raw target coverage, filtering somatic mutations attributable to clonal hematopoiesis. Plasma NGS sensitivity for known oncogenic drivers was $75 \%(N=68 / 91)$, and the specificity was $100 \%(N=19 / 19)$ [102].

In contrast, germline mutations can also complicate ctDNA testing as their mere presence does not necessarily imply a cancerous process. However, a high allele 
fraction (typically between 30 and 70\%) is suspicious for a germline variant than a somatic hit [103].

On a different note, caution must be taken when performing liquid biopsy testing in pregnant women. The fact that fetal cfDNA are shed into the maternal bloodstream [104] may obscure the interpretation.

The optimal timing of ctDNA testing also needs to be further evaluated in prospective studies. While Chen et al. suggested utilizing ctDNA detection on the third day after R0 resection as the post-operative baseline value [105], Szpechcinski et al. reported a drastic increase in plasma DNA levels a week after primary tumor resection, likely due to the surgical trauma [106]. In the metastatic setting, peak concentration of ctDNA early after the start of therapy was reported [107], which is also likely related to the rapid release of tumor DNA by treatment-induced tumor cell death. Distinguishing these and actual residual/resistant disease must be examined further.

In addition to the timing, the definition of a "positive" MRD, as well as standardized criteria to define "response" and "progression" or "relapse" during longitudinal monitoring, are critical to minimize variations among studies and provide reliable practices.

\section{Challenges and the prospect of ncRNAs as biomarkers}

The unstable nature and very short half-life of naked ncRNAs in plasma compared to ctDNA is a challenge for ncRNAs to be considered as biomarkers [108]. The stability of ctRNA is also dependent on the complexes they form. For example, miRNA in microvesicles are resistant to RNase-mediated degradation compared to protein-bound miRNA [109]. It is indeed difficult for an individual ctRNA to qualify as a candidate biomarker because of its overlapping levels in patients and healthy controls, limiting its sensitivity and specificity [110]. However, there are some advantages of ncRNAs over ctDNAs. The ctDNAs levels in the circulation are very low (between $0.01-1 \%$ of total cfDNA), whereas, ncRNAs are far more abundant than ctDNAs. Dysregulation of ncRNAs in different biofluids is frequent, even in the earliest stages of cancer $[4,111]$. A combination of various ncRNAs and other established circulation nucleic acids should be considered to enhance ncRNAs' potential as a non-invasive biomarker.

\section{Cost}

Collaborators of Ontario Health conducted a systematic review. They determined that utilizing liquid biopsy as a triage test before performing a tissue biopsy was more cost-effective in the setting of detecting EGFR T790M resistance mutation post 1 st or 2 nd generation EGFR TKIs, as the estimated cost was $\$ 700$ for a liquid biopsy vs. $\$ 2500$ for a tissue biopsy [112]. Furthermore, upfront
NGS testing in patients with metastatic NSCLC can have substantial cost reductions compared to single-gene testing for both Centers for Medicare \& Medicaid Services and US commercial payers [113]. The cost-effectiveness of molecular testing in early-stage NSCLC needs further evaluation. It is estimated that the cost of a personalized ctDNA profiling per patient for sequencing of a single tumor region, synthesis of a patient-specific assay panel, and profiling of five plasma samples is US \$1750 [17].

\section{Future directions}

Detecting and targeting ctDNA, particularly those with sensitizing molecular mutations, such as EGFR, would be especially beneficial in NSCLC with the availability of specific targeted inhibitors. In the recently reported ADAURA study, adjuvant osimertinib demonstrated a $79 \%$ reduction in the disease recurrence risk or death in resected stage IB-IIIA EGFR-mutated NSCLC patients (DFS HR 0.21, 95\% CI 0.16-0.28, $p<0.0001$ ) [114]. In addition to erlotinib, the ongoing ALCHEMIST study is evaluating the utility of crizotinib (ALK inhibitor) and nivolumab (PD1 inhibitor) in completely resected NSCL $C$ post standard care adjuvant therapy. Many other studies are assessing the role of chemotherapy with or without additional treatments, such as immunotherapy in the adjuvant setting. Table 2 shows the ongoing studies utilizing ctDNA monitoring in early-stage NSCLC.

While detectable plasma ctDNA post-surgery appears promising to utilize as a biomarker for MRD, the interpretation of a negative ctDNA test could be a challenge; as there are limitations to the detection sensitivity and there always will remain a chance of false-negative testing. To minimize the deleterious consequences of diagnosing a patient with a false-negative ctDNA result as "cancer-free", further long-term prospective studies utilizing serial plasma ctDNA monitoring post-resection with endpoints in OS would be of benefit.

At this time, the most robust evidence in liquid biopsies is reported from NSCLC studies, but recently, the role of liquid biopsies are being expanded into multiple tumor types.

Although the National Comprehensive Cancer Network (NCCN) guidelines recommend $R A S, B R A F$, and MSI or mismatch repair deficiency (dMMR) testing for all patients with metastatic colon cancer [115], a retrospective study showed that only $40 \%$ of these patients received guideline-recommended testing [116]. Direct comparison of tumor tissue-based approach vs. plasmabased ctDNA testing has shown concordance in detecting $A P C$, TP53, KRAS, NRAS, and BRAF mutations in treating naïve and non-anti-EGFR-treated cohorts of colorectal cancer [117]. With limited tissue availability in some patients, utilizing ctDNA for detecting these markers could increase the number of patients being 
Table 2 Ongoing studies utilizing ctDNA monitoring in early-stage NSCLC

\begin{tabular}{|c|c|c|c|c|c|}
\hline NCT\# & Type & Scope & Cohorts/Arms & $\begin{array}{l}\text { Primary outcome } \\
\text { measures }\end{array}$ & $\begin{array}{l}\text { Number } \\
\text { to be } \\
\text { enrolled }\end{array}$ \\
\hline NCT04367311 & Phase 2 & $\begin{array}{l}\text { Adjuvant chemo + atezolizumab in } \\
\text { resected NSCLC and clearance of } \\
\text { ctDNA }\end{array}$ & $\begin{array}{l}\text { Non-squam: cisplatin, pemetrexed, atezo } \\
\text { Squam: cis, docetaxel, atezo }\end{array}$ & $\begin{array}{l}\text { Percentage of pts. with } \\
\text { undetectable ctDNA } \\
\text { post adjuvant treatment }\end{array}$ & 100 \\
\hline NCT04267237 & Phase 2 & $\begin{array}{l}\text { Atezolizumab +/- RO7198457 } \\
\text { (personalized cancer vaccine) } \\
\text { following adjuvant chemo in ctDNA } \\
\text { positive pts. post resection }\end{array}$ & Atezo, atezo + RO7198457 & DFS & 80 \\
\hline NCT01629498 & Phase $1 / 2$ & $\begin{array}{l}\text { Intensity modulated photon (IMRT) } \\
\text { or proton radiation in stage II-IIIB } \\
\text { NSCLC }\end{array}$ & IMRT or proton radiation therapy & $\begin{array}{l}\text { MTD of IMRT and } \\
\text { proton therapy }\end{array}$ & 100 \\
\hline NCT03521154 & Phase 3 & $\begin{array}{l}\text { Osimertinib following } \\
\text { chemoradiation in stage III NSCLC } \\
\text { (LAURA) }\end{array}$ & Osimertinib, placebo & PFS & 200 \\
\hline NCT04385368 & Phase 3 & $\begin{array}{l}\text { Durvalumab with chemo in } \\
\text { resected stage II-III NSCLC (MERM } \\
\text { AID-1) }\end{array}$ & Chemotherapy + durvalumab/placebo & $\begin{array}{l}\text { DFS in MRD positive } \\
\text { analysis set }\end{array}$ & 332 \\
\hline NCT03774758 & Observational & $\begin{array}{l}\text { Biomarkers for risk stratification in } \\
\text { lung cancer }\end{array}$ & $\begin{array}{l}\text { Benign nodule on screening, incidental } \\
\text { benign nodule, presumed lung cancer, } \\
\text { suspicious nodule, suspicious incidental } \\
\text { nodule, post-treatment lung cancer }\end{array}$ & $\begin{array}{l}\text { Sensitivity and specificity } \\
\text { of ct-DNA LUNAR assay, }\end{array}$ & 590 \\
\hline NCT03553550 & Observational & $\begin{array}{l}\text { Role of ctDNA from liquid biopsy in } \\
\text { resected lung tumor (LIBERTI) }\end{array}$ & Completely resected early stage NSCLC & $\begin{array}{l}\text { Correlation between } \\
\text { ctDNA after surgery with } \\
\text { DFS }\end{array}$ & 500 \\
\hline NCT03517332 & Observational & $\begin{array}{l}\text { ctDNA exposure in peripheral } \\
\text { blood }\end{array}$ & $\begin{array}{l}\text { Healthy volunteer, those with stage 0-IV } \\
\text { cancer (i.e. lung, colon, pancreatic) }\end{array}$ & $\begin{array}{l}\text { ctDNA exposure in } \\
\text { peripheral blood using a } \\
\text { novel process, a } \\
\text { feasibility study }\end{array}$ & 10,000 \\
\hline NCT04354064 & Observational & $\begin{array}{l}\text { ctDNA for early treatment response } \\
\text { assessment of solid tumors }\end{array}$ & $\begin{array}{l}\text { Healthy volunteer, those with stage I-IV } \\
\text { solid tumors (i.e. lung, breast, colon) }\end{array}$ & $\begin{array}{l}\text { Freedom from } \\
\text { progression }\end{array}$ & 3362 \\
\hline $\begin{array}{l}\text { NCT03838588 } \\
\text { (China) }\end{array}$ & Observational & $\begin{array}{l}\text { Tracking molecular evolution for } \\
\text { NSCLC (T-MENC) }\end{array}$ & $\begin{array}{l}\text { Monitoring of ctDNA in stage IB, II, IIIA } \\
\text { NSCLC post resection }\end{array}$ & $\begin{array}{l}\text { Clonal evolution } \\
\text { assessed with liquid } \\
\text { biopsy, concordance of } \\
\text { ctDNA with PFS and OS }\end{array}$ & 200 \\
\hline
\end{tabular}

tested and increase the chance of receiving appropriate targeted therapies. Besides, ctDNA could be used to predict resistance to anti-EGFR therapy. Diaz et al. found that $40 \%$ of the patients with metastatic colon cancer, who were initially KRAS wild-type, developed detectable KRAS mutations in their serum using ctDNA after 5-6 months of anti-EGFR therapy with panitumumab [118]. In stage III of colon cancer, Tie et al. reported a significant difference in the 3-year recurrence-free interval in patients with detectable vs. undetectable levels of ctDNA after surgery (47\%vs 76\%, HR 3.8; $p<0.001$ ) and after completion of chemotherapy (30\% vs. 77\%, HR 0.75; p < 0.001) [119]. This suggests that post-surgical and postchemotherapy ctDNA analyses may identify patients with stage III colon cancer with a high risk of recurrence. Prospective randomized trials (NCT04068103, NCT03803553) are underway to answer these critical questions.

In resectable pancreatic cancer, Groot et al. monitored ctDNA in 59 patients using ddpcr to detect the most commonly seen somatic KRAS mutations (G12D, G12V, G12R, and Q61H) [120]. ctDNA was detected in about $50 \%$ of the patients before resection, and this was a strong predictor for worse PFS and OS. Those who received neoadjuvant chemotherapy were less likely to have detectable preoperative ctDNA (21\% vs. $70 \%$; $p<$ $0.001)$. Detecting ctDNA post-resection was associated with worse OS.

Late recurrence may also be detected by ctDNA in specific settings. A secondary analysis with ctDNA was done in hormone receptor-positive HER2-negative operable breast cancer patients from a randomized clinical study. Presence of ctDNA approximately 5 years after the initial diagnosis positively correlated with late disease recurrence [121].

Interestingly, there is data to support the use of ctDNA testing even in patients with cancers of unknown origin (CUP). Kato et al. reported the genomic landscape of ctDNA testing in 442 patients with CUP. Overall, 80\% of patients $(N=353 / 442)$ had detectable ctDNA and 
66\% $(N=290 / 442)$ had at least one characterized alteration, and most $(N=289 / 290)$ had an alteration that would be hypothetically targetable [122].

Combining different ctRNAs is one strategy to enhance the sensitivity and specificity as a biomarker for assessing disease detection and progression with increased precision. Simultaneous detection of two mRNAs and a lncRNA in serum exosomes was shown to have more excellent diagnostic value in colorectal cancer [123]. The lack of consensus on an optimal method [108] needs to be overcome for less variable recovery rates for the processing of samples. Notably, the advent of a lab-on-a-chip microdevice technology may allow rapid processing of samples [124]. The microfluidic system called integrated comprehensive droplet digital detection (IC3D) can detect a very low level of miRNAs in plasma within few hours [125]. With the promising potential as a biomarker in different cancer progression stages, the recently identified ctRNAs warrant further validation studies.

\section{Conclusions}

Liquid biopsy approaches utilizing ctDNA, miRNA, and lncRNA have a significant potential to improve patient care. Further prospective studies are warranted to optimize their use in early-stage NSCLC.

\begin{abstract}
Abbreviations
AE: Adverse events; ALK: Anaplastic lymphoma kinase; APC: Adenomatous polyposis coli; AUC: Area under the curve; BEAMing: Beads emulsion amplification magnetics; BRAF: V-raf murine sarcoma viral oncogene homolog B1; CAPP-Seq: Cancer personalized profiling by deep sequencing; Cl: Confidence interval; cfDNA: Cell free DNA; circRNA: Circular RNA; ctDNA: Circulating tumor DNA; ctRNA: Circulating tumor RNA; ddPCR: Droplet digital PCR; dMMR: Mismatch repair deficiency; dPCR: Digital PCR; EGFR: Epidermal growth factor receptor; ERBB2: Erythroblastic oncogene B; FDA: Food and drug administration; HER2: Human epidermal growth factor receptor 2; HR: Hazard ratio; IASLC: International association for the study of lung cancer; iDES: Integrated digital error suppression; KRAS: Kirsten rat sarcoma viral oncogene homolog; LCS: Let-7 complementary sites; IncRNA: Long non-coding RNA; MET: Mesenchymal epithelial transition factor; miRNA: Micro RNA; MRD: Minimal residual disease; MSI: Microsatellite instability; ncRNA: Non-coding RNA; NCCN: National comprehensive cancer network; NGS: Next generation sequencing; NRAS: Neuroblastoma ras viral oncogene homolog; NSCLC: Non-small cell lung cancer; ORR: Objective response rate; OS: Overall survival; PIK3CA: Phosphatidylinositol-4,5bisphosphate 3-kinase catalytic subunit alpha; piRNA: Piwi interacting RNA; PFS: Progression-free survival; qPCR: Quantitative PCR; RET: Rearranged during transfection; ROC: Receiver operating characteristics; Safe-Seq: Safesequencing; SNP: Single nucleotide polymophisms; snRNA: Small nuclear RNA; snoRNA: Small nucleolar RNA; TAM-Seq: Tagged amplicon deep sequencing; TKI: Tyrosine kinase inhibitor; TMB: Tumor mutational burden; TP53: Tumor protein 53; tRNA: Transfer RNA; WES: Whole-exome sequencing
\end{abstract}

\section{Acknowledgments}

NA

\section{Authors' contributions}

Dr. Nagasaka and Dr. Uddin developed the first draft of the manuscript. All authors contributed to the planning, organization, data collection, and writing of the manuscript. All reviewed the manuscript and provided critical edits. The final version of the manuscript was approved by all authors.

\section{Funding}

Dr. Nagasaka has been awarded the 2020 Karmanos Cancer Institute Cancer Immunology and Immunotherapy Pilot Award (P30 CA022453).

This research did not receive any specific grant from funding agencies in the public, commercial, or not-for-profit sectors.

\section{Availability of data and materials}

NA

\section{Declarations}

\section{Ethics approval and consent to participate}

NA

\section{Consent for publication}

NA

\section{Competing interests}

The authors have not received any funding for this study and declare no direct conflict of interest. Dr. Nagasaka serves on the advisory board for AstraZeneca, Caris Life Sciences, Daiichi-Sankyo, Takeda, Novartis, EMD Serono and has received study funding from Tempus. Dr. Sukari serves on the advisory board for Merck and Eisai. He has received study funding from Eisai. Dr. Azmi received funding from Karyopharm, EISAl, Janssen and serves as a consultant for GLG and Guidepoint. All other authors have no potential conflict of interest to declare.

\section{Author details}

${ }^{1}$ Department of Oncology, Wayne State University School of Medicine, Karmanos Cancer Institute, 4100 John R, Detroit, MI 48201, USA. Division of Neurology, Department of Internal Medicine, St. Marianna University School of Medicine, Kawasaki, Kanagawa, Japan. ${ }^{3}$ Department of Cell and Molecular Biology, Grand Valley State University, Allendale, MI 49401, USA

Received: 1 November 2020 Accepted: 13 May 2021

Published online: 01 June 2021

\section{References}

1. De Rubis G, Rajeev Krishnan S, Bebawy M. Liquid biopsies in cancer diagnosis, monitoring, and prognosis. Trends Pharmacol Sci 2019;40(3):172186. https://doi.org/10.1016/j.tips.2019.01.006.

2. Pisetsky DS, Fairhurst AM. The origin of extracellular DNA during the clearance of dead and dying cells. Autoimmunity 2007:40(4):281-284. https://doi.org/10.1080/08916930701358826.

3. Murtaza M, Dawson SJ, Pogrebniak K, Rueda OM, Provenzano E, Grant J, et al. Multifocal clonal evolution characterized using circulating tumour DNA in a case of metastatic breast cancer. Nat Commun 2015:6:8760. https://doi.org/10.1038/ncomms9760.

4. Diehl F, Schmidt K, Choti MA, Romans K, Goodman S, Li M, Thornton K, Agrawal N, Sokoll L, Szabo SA, Kinzler KW, Vogelstein B, Diaz Jr LA Circulating mutant DNA to assess tumor dynamics. Nat Med 2008;14(9):985-990. https://doi.org/10.1038/nm.1789.

5. EWH T, Chan KCA, Leung S, et al. Rapid clearance of plasma Epstein-Barr virus DNA after surgical treatment of nasopharyngeal carcinoma. Clin Cancer Res. 2003;9(9):3254-9.

6. Lo YM, Zhang J, Leung TN, Lau TK, Chang A, Hjelm NM. Rapid clearance of fetal DNA from maternal plasma. Am J Hum Genet 1999;64(1):218-224. https://doi.org/10.1086/302205.

7. Cheng ML, Pectasides Ririni, Hanna GJ, Parsons HA, Choudhury AD, Oxnard GR. Circulating tumor DNA in advanced solid tumors: clinica relevance and future directions. CA Cancer J Clin 2021; 71(2):176-190. https://doi.org/1 0.3322/caac. 21650

8. Bettegowda C, Sausen M, Leary RJ, et al. Detection of circulating tumor DNA in early- and late-stage human malignancies. Sci Transl Med 2014; 6(224):224ra24. https://doi.org/10.1126/scitranslmed.3007094.

9. Diehl F, Li M, Dressman D, et al. Detection and quantification of mutations in the plasma of patients with colorectal tumors. Proc Natl Acad Sci U S A 2005; 102(45):16368-16373. https://doi.org/10.1073/pnas.0507904102.

10. Newman AM, Bratman SV, To J, Wynne JF, Eclov NC, Modlin LA et al. An ultrasensitive method for quantitating circulating tumor DNA with broad 
patient coverage. Nat Med 2014;20(5):548-554. https://doi.org/10.1038/nm.3 519.

11. Forshew T, Murtaza M, Parkinson C, Gale D, Tsui DW, Kaper F, et al. Noninvasive identification and monitoring of cancer mutations by targeted deep sequencing of plasma DNA. Sci Transl Med 2012;4(136):136ra68. https://doi.org/10.1126/scitrans/med.3003726.

12. Kinde I, Wu J, Papadopoulos N, Kinzler KW, Vogelstein B. Detection and quantification of rare mutations with massively parallel sequencing. Proc Natl Acad Sci U S A 2011;108(23):9530-9535. https://doi.org/10.1073/pnas.11 05422108.

13. Kennedy SR, Schmitt MW, Fox EJ, Kohrn BF, Salk JJ, Ahn EH, et al. Detecting ultralow-frequency mutations by duplex sequencing. Nat Protoc 2014;9(11): 2586-2606. https://doi.org/10.1038/nprot.2014.170.

14. Newman AM, Lovejoy AF, Klass DM, Kurtz DM, Chabon JJ, Scherer F, et al. Integrated digital error suppression for improved detection of circulating tumor DNA. Nat Biotechnol 2016;34(5):547-555. https://doi.org/10.1038/ nbt.3520.

15. Guo N, Lou F, Ma Y, Li J, Yang B, Chen W, et al. Circulating tumor DNA detection in lung cancer patients before and after surgery. Sci Rep. 2016;6: 33519.

16. Chen K, Zhang J, Guan T, Yang F, Lou F, Chen W, et al. Comparison of plasma to tissue DNA mutations in surgical patients with non-small cell lung cancer. J Thorac Cardiovasc Surg 2017;154(3):1123-1131.e2. https://doi. org/10.1016/j.jtcvs.2017.04.073.

17. Chaudhuri AA, Chabon JJ, Lovejoy AF, Newman AM, Stehr H, Azad TD, Khodadoust MS, Esfahani MS, Liu CL, Zhou L, Scherer F, Kurtz DM, Say C, Carter JN, Merriott DJ, Dudley JC, Binkley MS, Modlin L, Padda SK, Gensheimer MF, West RB, Shrager JB, Neal JW, Wakelee HA, Loo Jr BW, Alizadeh AA, Diehn M Early detection of molecular residual disease in localized lung cancer by circulating tumor DNA profiling. Cancer Discov 2017;7(12):1394-1403. https://doi.org/10.1158/2159-8290.CD-17-0716.

18. Abbosh C, Birkbak NJ, Wilson GA, Jamal-Hanjani M, Constantin T, Salari R, et al. Phylogenetic ctDNA analysis depicts early-stage lung cancer evolution. Nature 2017;545(7655):446-451. https://doi.org/10.1038/nature22364.

19. Leighl NB, Page RD, Raymond VM, Daniel DB, Divers SG, Reckamp KL, Villalona-Calero MA, Dix D, Odegaard JI, Lanman RB, Papadimitrakopoulou VA Clinical utility of comprehensive cell-free DNA analysis to identify genomic biomarkers in patients with newly diagnosed metastatic non-small cell lung cancer. Clin Cancer Res 2019;25(15):4691-4700. https://doi.org/1 0.1158/1078-0432.CCR-19-0624

20. Aggarwal C, Thompson JC, Black TA, Katz SI, Fan R, Yee SS, Chien AL, Evans TL, Bauml JM, Alley EW, Ciunci CA, Berman AT, Cohen RB, Lieberman DB, Majmundar KS, Savitch SL, Morrissette JJD, Hwang WT, Elenitoba-Johnson KSJ, Langer CJ, Carpenter EL Clinical implications of plasma-based genotyping with the delivery of personalized therapy in metastatic nonsmall cell lung cancer. JAMA Oncol 2019;5(2):173-180. https://doi.org/10.1 001/jamaoncol.2018.4305.

21. Thress KS, Paweletz CP, Felip E, Cho BC, Stetson D, Dougherty B, Lai Z, Markovets A, Vivancos A, Kuang Y, Ercan D, Matthews SE, Cantarini M, Barrett JC, Jänne PA, Oxnard GR Acquired EGFR C797S mutation mediates resistance to AZD9291 in non-small cell lung cancer harboring EGFR T790M. Nat Med 2015;21(6):560-562. https://doi.org/10.1038/nm.3854.

22. Ortiz-Cuaran S, Scheffler M, Plenker D, Dahmen L, Scheel AH, FernandezCuesta $L$, et al. Heterogeneous mechanisms of primary and acquired resistance to third-generation EGFR inhibitors. Clin Cancer Res 2016;22(19): 4837-4847. https://doi.org/10.1158/1078-0432.CCR-15-1915.

23. Le X, Puri S, Negrao MV, Nilsson MB, Robichaux J, Boyle T, et al. Landscape of EGFR-dependent and-independent resistance mechanisms to osimertinib and continuation therapy beyond progression in EGFR-mutant NSCLC. Clin Cancer Res 2018;24(24):6195-6203. https://doi.org/10.1158/1 078-0432.CCR-18-1542.

24. Guibert N, Hu Y, Feeney N, Kuang Y, Plagnol V, Jones G, et al. Ampliconbased next-generation sequencing of plasma cell-free DNA for detection of driver and resistance mutations in advanced non-small cell lung cancer. Ann Oncol 2018;29(4):1049-1055. https://doi.org/10.1093/annonc/mdy005.

25. Shaw AT, Solomon BJ, Besse B, Bauer TM, Lin CC, Soo RA, et al. ALK resistance mutations and efficacy of lorlatinib in advanced anaplastic lymphoma kinase-positive non-small-cell lung cancer. J Clin Oncol 2019: 37(16):1370-1379. https://doi.org/10.1200/JCO.18.02236.

26. Rolfo C, Mack PC, Scagliotti GV, Baas P, Barlesi F, Bivona TG, Herbst RS, Mok TS, Peled N, Pirker R, Raez LE, Reck M, Riess JW, Sequist LV, Shepherd FA,
Sholl LM, Tan DSW, Wakelee HA, Wistuba II, Wynes MW, Carbone DP, Hirsch FR, Gandara DR Liquid biopsy for advanced non-small cell lung cancer (NSCLC): A statement paper from the IASLC. J Thorac Oncol 2018;13(9): 1248-1268. https://doi.org/10.1016/j.jtho.2018.05.030.

27. Wu YL, Zhou C, Liam CK, Wu G, Liu X, Zhong Z, Lu S, Cheng Y, Han B, Chen L, Huang C, Qin S, Zhu Y, Pan H, Liang H, Li E, Jiang G, How SH, Fernando $M C L$, Zhang $Y$, Xia F, Zuo Y First-line erlotinib versus gemcitabine/cisplatin in patients with advanced EGFR mutation-positive non-small-cell lung cancer: analyses from the phase III, randomized, open-label, ENSURE study. Ann Oncol 2015;26(9):1883-1889. https://doi.org/10.1093/annonc/mdv270.

28. Yang JC, Ahn MJ, Kim DW, Ramalingam SS, Sequist LV, Su WC, et al. Osimertinib in pretreated T790M-positive advanced non-small-cell lung cancer: AURA study phase II extension component. J Clin Oncol 2017;35(12): 1288-1296. https://doi.org/10.1200/JCO.2016.70.3223.

29. Goss G, Tsai CM, Shepherd FA, Bazhenova L, Lee JS, Chang GC, Crino L, Satouchi M, Chu Q, Hida T, Han JY, Juan O, Dunphy F, Nishio M, Kang JH, Majem M, Mann H, Cantarini M, Ghiorghiu S, Mitsudomi T Osimertinib for pretreated EGFR Thr790Met-positive advanced non-small-cell lung cancer (AURA2): a multicentre, open-label, single-arm, phase 2 study. Lancet Oncol 2016;17(12):1643-1652. https://doi.org/10.1016/S1470-2045(16)30508-3.

30. Douillard JY, Ostoros G, Cobo M, Ciuleanu T, McCormack R, Webster A, Milenkova T First-line gefitinib in Caucasian EGFR mutation-positive NSCLC patients: a phase-IV, open-label, single-arm study. Br J Cancer 2014;110(1): 55-62. https://doi.org/10.1038/bjc.2013.721.

31. Ramalingam SS, Vansteenkiste J, Planchard D, Cho BC, Gray JE, Ohe Y, et al. Overall survival with osimertinib in untreated, EGFR-mutated advanced NSCLC. N Engl J Med 2020;382(1):41-50. https://doi.org/10.1056/NEJMoa1 913662.

32. Vendrell JA, Quantin X, Serre I, Solassol J. Combination of tissue and liquid biopsy molecular profiling to detect transformation to small cell lung carcinoma during osimertinib treatment. Ther Adv Med Oncol 2020;12: 1758835920974192. https://doi.org/10.1177/1758835920974192.

33. Pignon JP, Tribodet H, Scagliotti GV, Douillard JY, Shepherd FA, Stephens RJ, et al. Lung adjuvant cisplatin evaluation: a pooled analysis by the LACE collaborative group. J Clin Oncol 2008;26(21):3552-3559. https://doi.org/1 0.1200/JCO.2e007.13.9030.

34. Antonia SJ, Villegas A, Daniel D, Vicente D, Murakami S, Hui R, et al. Overall survival with durvalumab after chemotherapy in stage III NSCLC. N Engl J Med. 2018:379(24):2342-50.

35. Jamal-Hanjani M, Wilson GA, Horswell S, et al. Detection of ubiquitous and heterogeneous mutations in cell-free DNA from patients with early-stage non-small-cell lung cancer. Ann Oncol. 2016;27:862-7.

36. Mok T, Wu YL, Lee JS, Yu CJ, Sriuranpong V, Sandoval-Tan J, et al. Detection and dynamic changes of EGFR mutations from circulating tumor DNA as a predictor of survival outcomes in NSCLC patients treated with first-line intercalated erlotinib and chemotherapy. Clin Cancer Res 2015;21(14):31963203. https://doi.org/10.1158/1078-0432.CCR-14-2594.

37. Taus Á, Camacho L, Rocha P, Hardy-Werbin M, Pijuan L, Piquer G, et al. Dynamics of EGFR mutation load in plasma for prediction of treatment response and disease progression in patients with EGFR-mutant lung adenocarcinoma. Clin Lung Cancer 2018;19(5):387-394.e2. https://doi.org/1 0.1016/j.cllc.2018.03.015.

38. Goldberg SB, Narayan A, Kole AJ, Decker RH, Teysir J, Carriero NJ, et al. Early assessment of lung cancer immunotherapy response via circulating tumor DNA. Clin Cancer Res 2018;24(8):1872-1880. https://doi.org/10.1158/10780432.CCR-17-1341.

39. Lee JH, Long GV, Menzies AM, Lo S, Guminski A, Whitbourne K, et al. Association between circulating tumor DNA and pseudoprogression in patients with metastatic melanoma treated with anti-programmed cell death 1 antibodies. JAMA Oncol 2018;4(5):717-721. https://doi.org/10.1001/ jamaoncol.2017.5332.

40. Rizvi NA, Hellmann MD, Snyder A, Kvistborg P, Makarov V, Havel J, et al. Mutational landscape determines sensitivity to PD-1 blockade in non-small cell lung cancer. Science 2015;348(6230):124-128. https://doi.org/10.1126/ science.aaa1348

41. Hellmann MD, Ciuleanu TE, Pluzanski A, Lee JS, Otterson GA, AudigierValette $C$, et al. Nivolumab plus ipilimumab in lung cancer with a high tumor mutational burden. N Engl J Med 2018;378(22):2093-2104. https:// doi.org/10.1056/NEJMoa1801946.

42. Frampton GM, Fichtenholtz A, Otto GA, Wang K, Downing SR, He J, SchnallLevin M, White J, Sanford EM, An P, Sun J, Juhn F, Brennan K, Iwanik K, 
Maillet A, Buell J, White E, Zhao M, Balasubramanian S, Terzic S, Richards T, Banning V, Garcia L, Mahoney K, Zwirko Z, Donahue A, Beltran H, Mosquera JM, Rubin MA, Dogan S, Hedvat CV, Berger MF, Pusztai L, Lechner M, Boshoff C, Jarosz M, Vietz C, Parker A, Miller VA, Ross JS, Curran J, Cronin MT, Stephens PJ, Lipson D, Yelensky R Development and validation of a clinical cancer genomic profiling test based on massively parallel DNA sequencing. Nat Biotechnol 2013;31(11):1023-1031. https://doi.org/10.1038/nbt.2696.

43. Gandara DR, Paul SM, Kowanetz M, Schleifman E, Zou W, Li Y, et al. Bloodbased tumor mutational burden as a predictor of clinical benefit in nonsmall-cell lung cancer patients treated with atezolizumab. Nat Med 2018; 24(9):1441-1448. https://doi.org/10.1038/s41591-018-0134-3.

44. Socinski M, Velcheti V, Mekhail T, Chae YK, Leal TA, Dowell JE, Tsai ML, Dakhil CS, Stella P, Shen V, Hu S, Paul SM, Shames DS, Schleifman E, Fabrizio DA, Nowicki M, Yun C, Phan S, Kim ES Final efficacy results from B-F1RST, a prospective phase II trial evaluating blood-based tumour mutational burden (bTMB) as a predictive biomarker for atezolizumab (atezo) in $1 \mathrm{~L}$ non-small cell lung cancer (NSCLC). Ann Oncol 2019;30(Suppl. 5):v919-v920. https:// doi.org/10.1093/annonc/mdz394.081.

45. Wang Z, Duan J, Cai S, Han M, Dong H, Zhao J, et al. Assessment of blood tumor mutational burden as a potential biomarker for immunotherapy in patients with non-small cell lung cancer with use of a next-generation sequencing cancer gene panel. JAMA Oncol 2019;5(5):696-702. https://doi. org/10.1001/jamaoncol.2018.7098.

46. Georgiadis A, Durham JN, Keefer LA, Bartlett BR, Zielonka M, Murphy D, et al. Noninvasive detection of microsatellite instability and high tumor mutation burden in cancer patients treated with PD-1 blockade. Clin Cancer Res 2019;25(23):7024-7034. https://doi.org/10.1158/1078-0432.CCR-19-1372.

47. Stroun M, Anker P, Beljanski M, Henri J, Lederrey C, Ojha M, et al. Presence of RNA in the nucleoprotein complex spontaneously released by human lymphocytes and frog auricles in culture. Cancer Res. 1978;38(10):3546-54.

48. Zaporozhchenko IA, Ponomaryova AA, Rykova EY, Laktionov PP. The potential of circulating cell-free RNA as a cancer biomarker: challenges and opportunities. Expert Rev Mol Diagn 2018;18(2):133-145. https://doi.org/10.1 080/14737159.2018.1425143.

49. Danielson KM, Rubio R, Abderazzaq F, Das S, Wang YE. High throughput sequencing of extracellular RNA from human plasma. PLoS One 2017;12(1): e0164644. https://doi.org/10.1371/journal.pone.0164644.

50. Nilsson RJA, Karachaliou N, Berenguer J, et al. Rearranged EML4-ALK fusion transcripts sequester in circulating blood platelets and enable blood-based crizotinib response monitoring in non-small-cell lung cancer. Oncotarget 2016;7(1):1066-1075. https://doi.org/10.18632/oncotarget.6279.

51. Lee RC, Feinbaum RL, Ambros V. The C. Elegans heterochronic gene lin-4 encodes small RNAs with antisense complementarity to lin-14. Cell 1993; 75(5):843-854. https://doi.org/10.1016/0092-8674(93)90529-y.

52. Wightman B, Ha I, Ruvkun G. Posttranscriptional regulation of the heterochronic gene lin-14 by lin-4 mediates temporal pattern formation in C. elegans. Cell 1993;75(5):855-862. https://doi.org/10.1016/0092-8674(93 )90530-4.

53. O'Brien J, Hayder H, Zayed Y, Peng C. Overview of MicroRNA biogenesis, mechanisms of actions, and circulation. Front Endocrinol (Lausanne) 2018;9: 402. https://doi.org/10.3389/fendo.2018.00402.

54. Bartel DP. MicroRNAs: target recognition and regulatory functions. Cell 2009; 136(2):215-233. https://doi.org/10.1016/j.cell.2009.01.002.

55. Carthew RW. Gene regulation by microRNAs. Curr Opin Genet Dev 2006; 16(2):203-208. https://doi.org/10.1016/j.gde.2006.02.012.

56. Duttagupta R, Jiang R, Gollub J, Getts RC, Jones KW. Impact of cellular miRNAs on circulating miRNA biomarker signatures. PLoS One 2011;6(6): e20769. https://doi.org/10.1371/journal.pone.0020769.

57. Umu SU, Langseth $\mathrm{H}$, Bucher-Johannessen C, Fromm B, Keller A, Meese E, et al. A comprehensive profile of circulating RNAs in human serum. R.N.A Biol 2018;15(2):242-250. https://doi.org/10.1080/15476286.2017.1403003.

58. Schwarzenbach H, Nishida N, Calin GA, Pantel K. Clinical relevance of circulating cell-free microRNAs in cancer. Nat Rev Clin Oncol 2014;11(3):145156. https://doi.org/10.1038/nrclinonc.2014.5.

59. Pigati L, Yaddanapudi SCS, lyengar R, Kim DJ, Hearn SA, Danforth D, Hastings ML, Duelli DM Selective release of microRNA species from normal and malignant mammary epithelial cells. PLoS One 2010;5(10):e13515. https://doi.org/10.1371/journal.pone.0013515.

60. Okada H, Kohanbash G, Lotze MT. MicroRNAs in immune regulation-opportunities for cancer immunotherapy. Int J Biochem Cell Biol 2010;42(8): 1256-1261. https://doi.org/10.1916/j.biocel.2010.02.002.
61. Cui M, Wang H, Yao X, et al. Circulating MicroRNAs in Cancer: potential and challenge. Front Genet 2019;10:626. https://doi.org/10.3389/fgene.2 019.00626.

62. Zhang WC, Chin TM, Yang H, Nga ME, Lunny DP, Lim EK, et al. Tumourinitiating cell-specific miR-1246 and miR-1290 expression converge to promote non-small cell lung cancer progression. Nat Commun 2016;7: 11702. https://doi.org/10.1038/ncomms11702, 1.

63. Chin LJ, Ratner E, Leng S, Zhai R, Nallur S, Babar I, et al. A SNP in a let-7 microRNA complementary site in the KRAS $3^{\prime}$ untranslated region increases non-small cell lung cancer risk. Cancer Res 2008;68(20):8535-8540. https:// doi.org/10.1158/0008-5472.CAN-08-2129.

64. Hu Z, Chen X, Zhao Y, Tian T, Jin G, Shu Y, et al. Serum microRNA signatures identified in a genome-wide serum microRNA expression profiling predict survival of non-small-cell lung cancer. J Clin Oncol 2010;28(10):1721-1726. https://doi.org/10.1200/JCO.2009.24.9342.

65. Cui E, Li H, Hua F, Wang B, Mao W, Feng XR, Li JY, Wang X Serum microRNA $125 \mathrm{~b}$ as a diagnostic or prognostic biomarker for advanced NSCL C patients receiving cisplatin-based chemotherapy. Acta Pharmacol Sin 2013;34(2):309-313. https://doi.org/10.1038/aps.2012.125.

66. Wang $H$, Tan G, Dong $L$, et al. Circulating MiR-125b as a marker predicting chemoresistance in breast cancer. PLoS One 2012;7(4):e34210. https://doi. org/10.1371/journal.pone.0034210.

67. Kong F, Sun C, Wang Z, et al. miR-125b confers resistance of ovarian cancer cells to cisplatin by targeting pro-apoptotic $\mathrm{BCl}-2$ antagonist killer 1. J Huazong Univ Sci Technolog Med Sci 2011;31(4):543. https://doi.org/10.1 007/s11596-011-0487-z.

68. Hawkins PG, Sun Y, Dess RT, Jackson WC, Sun G, Bi N, Tewari M, Hayman JA, Kalemkerian GP, Gadgeel SM, Lawrence TS, Haken RKT, Matuszak MM, Kong FM, Schipper M, Jolly S Circulating microRNAs as biomarkers of radiation-induced cardiac toxicity in non-small-cell lung cancer. J Cancer Res Clin Oncol 2019;145(6): 1635-1643. https//doi.org/10.1007/s00432-019-02903-5.

69. Zhao Y. The diagnostic and prognostic role of circulating miR-141 expression in non-small-cell lung cancer patients. Int J Clin Exp Pathol. 2018; 11(5):2597-604.

70. Xu X, Zhu S, Tao Z, Ye S. High circulating miR-18a, miR-20a, and miR-92a expression correlates with poor prognosis in patients with non-small cell lung cancer. Cancer Med 2018;7(1):21-31. https://doi.org/10.1002/ca m4.1238.

71. Abdollahi A, Rahmati S, Ghaderi B, Sigari N, Nikkhoo B, Sharifi K, et al. A combined panel of circulating microRNA as a diagnostic tool for detection of the non-small cell lung cancer. Q J M 2019;112(10):779-785. https://doi. org/10.1093/qjmed/hcz158.

72. Roa WH, Kim JO, Razzak R, du H, Guo L, Singh R, Gazala S, Ghosh S, Wong E, Joy AA, Xing JZ, Bedard EL Sputum microRNA profiling: a novel approach for the early detection of non-small cell lung cancer. Clin Invest Med 2012; 35(5):E271. https://doi.org/10.25011/cim.v35i5.18700.

73. Xie Y, Todd NW, Liu Z, et al. Altered miRNA expression in sputum for diagnosis of non-small cell lung cancer. Lung Cancer 2010;67(2):170-176. https://doi.org/10.1016/j.lungcan.2009.04.004.

74. Iyer MK, Niknafs YS, Malik R, Singhal U, Sahu A, Hosono Y, et al. The landscape of long non-coding RNAs in the human transcriptome. Nat Genet 2015;47(3):199-208. https://doi.org/10.1038/ng.3192.

75. Peng W, Wang J, Shan B, Peng Z, Dong Y, Shi W, He D, Cheng Y, Zhao W, Zhang C, Li B, Duan C Diagnostic and prognostic potential of circulating long non-coding RNAs in non small cell lung cancer. Cell Physiol Biochem 2018;49(2):816-827. https://doi.org/10.1159/000493043.

76. Guttman M, Amit I, Garber M, French C, Lin MF, Feldser D, et al. Chromatin signature reveals over a thousand highly conserved large non-coding RNAs in mammals. Nature 2009;458(7235):223-227. https://doi.org/10.1038/na ture07672.

77. Wapinski O, Chang HY. Long non-coding RNAs and human disease. Trends Cell Biol 2011;21(6):354-361. https://doi.org/10.1016/j.tcb.2011.04.001.

78. Wilusz JE, Sunwoo H, Spector DL. Long non-coding RNAs: functional surprises from the RNA world. Genes Dev 2009;23(13):1494-1504. https:// doi.org/10.1101/gad.1800909

79. Akhade VS, Pal D, Kanduri C. Long non-coding RNA: genome organization and mechanism of action. Adv Exp Med Biol 2017;1008:47-74. https://doi. org/10.1007/978-981-10-5203-3_2.

80. Tantai J, Hu D, Yang Y, Geng J. Combined identification of long non-coding RNA XIST and HIF1A-AS1 in serum as an effective screening for non-small cell lung cancer. Int J Clin Exp Pathol. 2015;8(7):7887-95. 
81. Zhang X, Guo H, Bao Y, Yu H, Xie D, Wang X. Exosomal long non-coding RNA DLX6-AS1 AS a potential diagnostic biomarker for non-small cell lung cancer. Oncol Lett 2019;18(5):5197-5204. https://doi.org/10.3892/ol.2019.1 0892.

82. Lv P, Yang S, Liu W, Qin H, Tang X, Wu F, et al. Circulating plasma IncRNAs as novel markers of EGFR mutation status and monitors of epidermal growth factor receptor-tyrosine kinase inhibitor therapy. Thorac Cancer 2020;11(1):29-40. https://doi.org/10.1111/1759-7714.13216.

83. Kamel LM, Atef DM, Mackawy AMH, Shalaby SM, Abdelraheim N. Circulating long non-coding RNA GAS5 and SOX2OT as potential biomarkers for diagnosis and prognosis of non-small cell lung cancer. Biotechnol Appl Biochem 2019;66(4):634-642. https://doi.org/10.1002/bab.1764.

84. Xie $Y$, Zhang Y, Du L, Jiang X, Yan S, Duan W, et al. Circulating long noncoding RNA act as potential novel biomarkers for diagnosis and prognosis of non-small cell lung cancer. Mol Oncol 2018;12(5):648-658. https://doi. org/10.1002/1878-0261.12188.

85. Hsu MT, Coca-Prados M. Electron microscopic evidence for the circular form of RNA in the cytoplasm of eukaryotic cells. Nature 1979;280(5720):339-340. https://doi.org/10.1038/280339a0.

86. Wang S, Zhang K, Tan S, et al. Circular RNAs in body fluids as cancer biomarkers: the new fontier of liquid biopsies. Mol Cancer 2021;20(1):13. https://doi.org/10.1186/s12943-020-01298-z.

87. Tucker D, Zheng W, Zhang D, Dong X. Circular RNA and its potential as prostate cancer biomarkers. World J Clin Oncol 2020;11(8):563-572. https:// doi.org/10.5306/wjco.v11.i8.563.

88. Du WW, Zhang C, Yang W, Yong T, Awan FM, Yang BB. Identifying and characterizing circRNA-protein interaction. Theranostics 2017;7(17):41834191. https://doi.org/10.7150/thno.21299.

89. Rong D, Sun H, Li Z, Liu S, Dong C, Fu K, Tang W, Cao H An emerging function of circRNA-miRNAs-mRNA axis in human diseases. Oncotarget 2017:8(42):73271-73281. https://doi.org/10.18632/oncotarget.19154.

90. Azmi AS. Nuclear export mechanisms of circular RNAs: size does matter. Non-coding RNA Investig 2018;2. https://doi.org/10.21037/ncri.2018.08.03.

91. Hang D, Zhou J, Qin N, Zhou W, Ma H, Jin G, Hu Z, Dai J, Shen H A novel plasma circular RNA circFARSA is a potential biomarker for non-small cell lung cancer. Cancer Med 2018;7(6):2783-2791. https://doi.org/10.1002/ca m4.1514.

92. Jeck WR, Sharpless NE. Detecting and characterizing circular RNAs. Nat Biotechnol 2014;32(5):453-461. https://doi.org/10.1038/nbt.2890.

93. Meng S, Zhou H, Feng Z, Xu Z, Tang Y, Li P, Wu M CircRNA: functions and properties of a novel potential biomarker for cancer. Mol Cancer 2017;16(1): 94. https://doi.org/10.1186/s12943-017-0663-2.

94. Qiu M, Xia W, Chen R, et al. The circular RNA circPRKCl promotes tumor growth in lung adenocarcinoma. Cancer Res 2018;78(11):2839-2851. https:// doi.org/10.1158/0008-5472.CAN-17-2808.

95. Liao J, Yu L, Mei Y, Guarnera M, Shen J, Li R, Liu Z, Jiang F Small nucleolar RNA signatures as biomarkers for non-small-cell lung cancer. Mol Cancer 2010;9:198. https://doi.org/10.1186/1476-4598-9-198, 1.

96. Su Y, Guarnera MA, Fang H, Jiang F. Small non-coding RNA biomarkers in sputum for lung cancer diagnosis. Mol Cancer 2016;15(1):36. https://doi. org/10.1186/s12943-016-0520-8.

97. Zhou S, Huang R, Cao Y. Detection of epidermal growth factor receptor mutations in peripheral blood circulating tumor DNA in patients with advanced non-small cell lung cancer: A PRISMA-compliant meta-analysis and systematic review. Medicine (Baltimore) 2020; 99(40):e21965. https://doi. org/10.1097/MD.0000000000021965.

98. Pollock PM, Harper UL, Hansen KS, Yudt LM, Stark M, Robbins CM, Moses TY, Hostetter G, Wagner U, Kakareka J, Salem G, Pohida T, Heenan P, Duray P, Kallioniemi O, Hayward NK, Trent JM, Meltzer PS High frequency of BRAF mutations in nevi. Nat Genet 2003;33(1):19-20. https://doi.org/10.1038/ng1054.

99. De Giorgi V, Pinzani P, Salvianti F, et al. Circulating benign nevus cells detected by ISET techniques: waning for melanoma molecular diagnosis. Arch Dermatol 2010;146(10):1120-1124. https://doi.org/10.1001/archderma tol.2010.264.

100. Jaiswal S, Fontanillas P, Flannick J, Manning A, Grauman PV, Mar BG, Lindsley RC, Mermel CH, Burtt N, Chavez A, Higgins JM, Moltchanov V, Kuo FC, Kluk MJ, Henderson B, Kinnunen L, Koistinen HA, Ladenvall C, Getz G, Correa A, Banahan BF, Gabriel S, Kathiresan S, Stringham HM, McCarthy MI, Boehnke M, Tuomilehto J, Haiman C, Groop L, Atzmon G, Wilson JG, Neuberg D, Altshuler D, Ebert BL Age-related clonal hematopoiesis associated with adverse outcomes. N Engl J Med 2014;371(26):2488-2498. https://doi.org/10.1056/NEJMoa1408617.

101. Hu Y, Ulrich BC, Supplee J, Kuang Y, Lizotte PH, Feeney NB, Guibert NM, Awad MM, Wong KK, Jänne PA, Paweletz CP, Oxnard GR False-positive plasma genotyping due to clonal hematopoiesis. Clin Cancer Res 2018; 24(18):4437-4443. https://doi.org/10.1158/1078-0432.CCR-18-0143.

102. Li BT, Janku F, Jung B, Hou C, Madwani K, Alden R, et al. Ultra-deep nextgeneration sequencing of plasma cell-free DNA in patients with advanced lung cancers: results from the actionable genome consortium. Ann Oncol 2019;30(4):597-603. https://doi.org/10.1093/annonc/mdz046.

103. Singh AP, Cheng H, Guo X, Levy B, Halmos B. Circulating tumor DNA in non-small-cell lung cancer: a primer for the clinician. J.C.O. Precis Oncol 2017;1:1-13. https://doi.org/10.1200/P0.17.00054

104. Bianchi DW, Chiu RWK. Sequencing of circulating cell-free DNA during pregnancy. N Engl J Med 2018;379(5):464-473. https://doi.org/10.1056/ NEJMra1705345.

105. Chen K, Zhao H, Shi Y, Yang F, Wang LT, Kang G, et al. Perioperative dynamic changes in circulating tumor DNA in patients with lung cancer (DYNAMIC). Clin Cancer Res 2019;25(23):7058-7067. https://doi.org/10.11 58/1078-0432.CCR-19-1213.

106. Szpechcinski A, Chorostowska-Wynimko J, Kupis W, Maszkowska-Kopij K, Dancewicz M, Kowalewski J, Orlowski T Quantitative analysis of freecirculating DNA in plasma of patients with resectable NSCLC. Expert Opin Biol Ther 2012;12(Suppl. 1):S3-S9. https://doi.org/10.1517/14712598.2012. 668519.

107. Vallée A, Audigier-Valette C, Herbreteau G, Merrien J, Tessonnier L, Théoleyre $S$, et al. Rapid clearance of circulating tumor DNA during treatment with AZD9291 of a lung cancer patient presenting the resistance EGFR T790M mutation. Lung Cancer 2016;91:73-74. https://doi.org/10.1016/j. lungcan.2015.11.008.

108. Sourvinou IS, Markou A, Lianidou ES. Quantification of circulating miRNAs in plasma: effect of preanalytical and analytical parameters on their isolation and stability. J Mol Diagn 2013;15(6):827-834. https://doi.org/10.1016/j. jmoldx.2013.07.005.

109. Winther TN, Bang-Berthelsen CH, Heiberg IL, Pociot F, Hogh B. Differential plasma microRNA profiles in $\mathrm{HBeAg}$ positive and $\mathrm{HBeAg}$ negative children with chronic hepatitis B. PLoS One. 2013;8(3):e58236 https://doi.org/10/ 1371/journal.pone.0058236.

110. Wang H, Peng R, Wang J, Qin Z, Xue L. Circulating microRNAs as potential cancer biomarkers: the advantage and disadvantage. Clin Epigenetics. 2018; 10(1):59. https://doi.org/10.1186/s13148-018-0492-1.

111. Shigeyasu K, Toden S, Zumwalt TJ, Okugawa Y, Goel A. Emerging role of microRNAs as liquid biopsy biomarkers in gastrointestinal cancers. Clin Cancer Res 2017;23(10):2391-2399. https://doi.org/10.1158/1078-0432.CCR-1 6-1676.

112. Ontario Health (Quality). Lambrinos A, Falk L, Gajic-Veljanoski O, et al. Cellfree circulating tumour DNA blood testing to detect EGFR T790M mutation in people with advanced non-small cell lung Cancer: A Health technology assessment. Ont Health Technol Assess Ser. 2020;20(5):1-176.

113. Pennell NA, Mutebi A, Zhou ZY, Ricculli ML, Tang W, Wang $H$, et al. Economic impact of next-generation sequencing versus single-gene testing to detect genomic alterations in metastatic non-small-cell lung cancer using a decision analytic model. J.C.O. Precis Oncol. 2019;3:1-9.

114. Wu YL, Tsuboi M, He J, John T, Grohe C, Majem M, Goldman JW, Laktionov K, Kim SW, Kato T, Vu HV, Lu S, Lee KY, Akewanlop C, Yu CJ, de Marinis F, Bonanno L, Domine M, Shepherd FA, Zeng L, Hodge R, Atasoy A, Rukazenkov $Y$, Herbst RS Osimertinib in resected EGFR-mutated non-smallcell lung Cancer. N Engl J Med. 2020;383(18):1711-23. https://doi.org/10.1 056/NEJMoa2027071.

115. National Comprehensive Cancer Network. Colon Cancer (Version 4.2020). https://www.nccn.org/professionals/physician_gls/pdf/colon.pdf. Accessed 21 Mar 2021.

116. Gutierrez ME, Price KS, Lanman RB, Nagy RJ, Shah I, Mathura S, et al. Genomic profiling for KRAS, NRAS, BRAF, microsatellite instability, and mismatch repair deficiency among patients with metastatic colon cancer. J. C.O. Precis Oncol. 2019;3:1-9.

117. Gupta R, Othman T, Chen C, Sandhu J, Ouyang C, Fakih M. Guardant360 circulating tumor DNA assay is concordant with FoundationOne nextgeneration sequencing in detecting actionable driver mutations in antiEGFR naïve metastatic colorectal cancer. Oncologist 2020;25(3):235-243. https://doi.org/10.1634/theoncologist.2019-0441. 
118. Diaz LA Jr., Williams RT, Wu J, Kinde I, Hecht JR, Berlin J, et al. The molecular evolution of acquired resistance to targeted EGFR blockade in colorectal cancers. Nature 2012;486(7404):537-540. https://doi.org/10.1 038/nature11219.

119. Tie J, Cohen JD, Wang Y, Christie M, Simons K, Lee M, et al. Circulating tumor DNA analyses as markers of recurrence risk and benefit of adjuvant therapy for stage III colon cancer. JAMA Oncol 2019;5(12):1710-1717. https://doi.org/10.1001/jamaoncol.2019.3616.

120. Groot VP, Mosier S, Javed AA, Teinor JA, Gemenetzis G, Ding D, et al. Circulating tumor DNA as a clinical test in resected pancreatic cancer. Clin Cancer Res 2019;25(16):4973-4984. https://doi.org/10.1158/1078-0432.CCR-1 9-0197.

121. Sparano J, O'Neill A, Alpaugh K, Wolff AC, Northfelt DW, Dang CT, Sledge GW, Miller KD Association of circulating tumor cells with late recurrence of estrogen receptor-positive breast cancer: a secondary analysis of a randomized clinical trial. JAMA Oncol 2018:4(12):1700-1706. https://doi. org/10.1001/jamaoncol.2018.2574

122. Kato S, Krishnamurthy N, Banks KC, De P, Williams K, Williams C, et al. Utility of genomic analysis in circulating tumor DNA from patients with carcinoma of unknown primary. Cancer Res 2017;77(16):4238-4246. https://doi.org/1 0.1158/0008-5472.CAN-17-0628.

123. Dong L, Lin W, Qi P, et al. Circulating Long RNAs in serum extracellular vesicles: their characterization and potential application as biomarkers for diagnosis of colorectal Cancer. Cancer Epidemiol Biomark Prev 2016;25(7): 1158-1166. https://doi.org/10.1158/1055-9965.EPI-16-0006.

124. Potrich C, Vaghi V, Lunelli L, et al. OncomiR detection in circulating body fluids: a PDMS microdevice perspective. Lab Chip 2014;14(20):4067-4075. https://doi.org/10.1039/c4lc00630e.

125. Zhang K, Kang D, Ali MM, et al. Digital quantification of miRNA directly in plasma using integrated comprehensive droplet digital detection. Lab Chip 2015;15(21):4217-4226. https://doi.org/10.1039/c5lc00650c.

\section{Publisher's Note}

Springer Nature remains neutral with regard to jurisdictional claims in published maps and institutional affiliations.

Ready to submit your research? Choose BMC and benefit from:

- fast, convenient online submission

- thorough peer review by experienced researchers in your field

- rapid publication on acceptance

- support for research data, including large and complex data types

- gold Open Access which fosters wider collaboration and increased citations

- maximum visibility for your research: over $100 \mathrm{M}$ website views per year

At $\mathrm{BMC}$, research is always in progress.

Learn more biomedcentral.com/submissions 